Article

\title{
The Contribution of Workers' Attributes on Sustainability of Construction Project Realization Goals-Survey on the Impact on Productivity in Croatia
}

\author{
Držislav Vidaković *, Marijana Hadzima-Nyarko@ and Saša Marenjak \\ Faculty of Civil Engineering and Architecture Osijek, Josip Juraj Strossmayer University of Osijek, \\ Vladimira Preloga 3, 31000 Osijek, Croatia; mhadzima@gfos.hr (M.H.-N.); sasa@pppcentar.com (S.M.) \\ * Correspondence: dvidak@gfos.hr
}

Received: 30 October 2020; Accepted: 24 November 2020; Published: 27 November 2020

\begin{abstract}
The work of workers is still dominant in the realization of most construction projects and therefore has a great impact on the productivity of contractors and, thereby, on the sustainability of realization of the goals of contractors and clients. This article provides an overview of the results of more than 100 studies from the previous decade on the impacts of factors related to the personal attributes of workers on the productivity and performance of construction projects. Based on the reviewed literature and semi-structured interviews with experienced professionals in the construction industry, the relation between worker characteristics and other influences on labor productivity is defined and a list of worker characteristics suitable for research in Croatia is compiled. A survey of 262 workers, engineers, and managers from construction industries of Croatia's eastern region, Slavonia and Baranja, showed that the worker characteristics that most influence labor productivity are experience and dexterity. It was also noticed, with a high correlation between the different groups of respondents, that physical strength and morale and morality of the workers were rated as highly influential, while education level was rated as the least influential. The research results are useful because they indicate the possibility of significantly improving the productivity of construction contractors by selecting workers with appropriate physical abilities and cognitive and non-cognitive skills, as well as developing a suitable system for training and motivation of employees.
\end{abstract}

Keywords: labor productivity; attributes of workers; project realization goals; impact rank; survey; Croatia; improvement measures

\section{Introduction}

Construction contractors must have good productivity to operate profitably, which means efficiently converting resources into marketable products [1]. The productivity of contractors has multiple impacts on their own business and the construction industry as a whole, as well as on other industries and the national economy [2]. At the construction projects level, improving the productivity of construction contractors reduces time and realization costs, allows for more competitive bids in job tenders, and creates the space to increase quality [3]. Productivity is positively correlated with the percentage of plan execution, i.e., the measure of changes in the work schedule [4], or, the sustainability of the initially set goals. Extending the realization deadline reduces the profit of construction contractors, and delays the possibility for clients to use the results of their investment and thus reduces their profitability [5]. Therefore, the subject of a large amount of research is the productivity of construction contractors and the factors that affect it. 
Construction is a labor-intensive industry and there is, usually, a large share of labor in project realization, although this largely depends on the type of project (the different types of work it consists of) and the construction contractor (available technology). The execution of most construction operations and processes is based on the performance of working groups and the productivity of contractors is mostly related to this [6]. Therefore, the term productivity of construction contractors usually refers to labor productivity. Labor productivity in construction is usually defined as the ratio of output to inputs in production [7], i.e., the amount of work realized in a unit time [3,8] or its reciprocal value $[1,9,10]$. Labor productivity is one of the most frequently used performance indicators of the success of realization of a construction project [11]. Contractor productivity mainly depends on human effort and worker performance [12] and, according to research provided by Nasir et al. [13], construction contractors consider human resource management to be a high priority with respect to assessing project performance in Canada. Figure 1 highlights the characteristics of workers as one of the main groups that influences the achievement of project performance assessment goals, which are in the domain of the contractor.

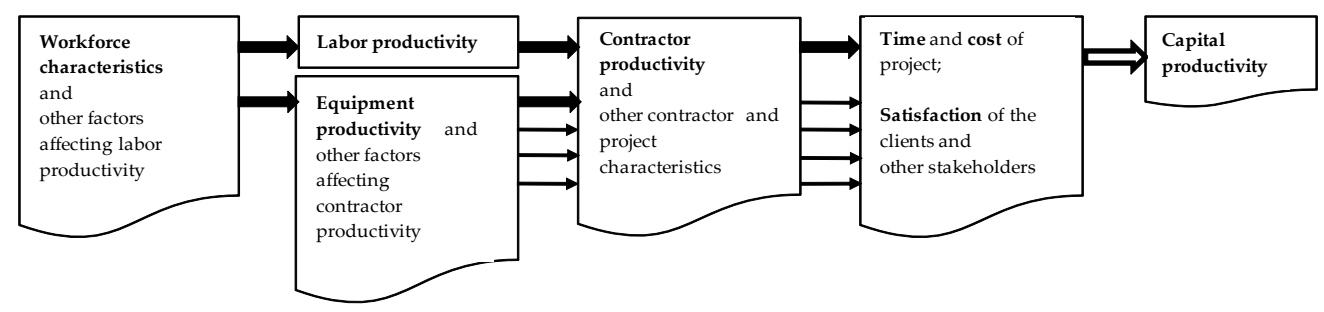

Figure 1. The chain of influence on productivity during the implementation of construction projects.

The productivity of construction contractors is a dynamic category dependent on many factors, in connection with which certain corrective measures can be taken in a timely manner. In order to be able to manage productivity comprehensively and successfully, it is necessary to determine which characteristics and how these characteristics of workers significantly affect labor productivity.

\section{Literature Review: Previous Research on the Influence of Labor Force Characteristics on Labor Productivity and the Performance of Construction Projects}

\subsection{The Influence of Labor Force on Achieving the Goals of Realization of Construction Projects}

Most research on the impact on construction performance or time (delay) and cost of realization of construction projects consider some of the attributes of the labor force as important influencing factors. Based on past research papers, Soekiman et al. [14] compiled a list of 113 factors affecting construction labor productivity. Of the total number of factors, 18 factors are included in the group "labor", and some of them are related to the personal attributes of workers. Zidane and Anderson [15] found out that, in 105 studies (1988-2017) from 46 countries worldwide, "poor labor productivity and shortening of skills" is 8 th in the top ten universal delay factors (that factor was cited in $45 \%$ of studies). Asmi et al. [16] reviewed 12 studies (1996-2009) and found that "labor productivity" is the 5th to 7 th factor of delay according to the frequency of appearance (in $42 \%$ of studies). Hesham et al. [17] reviewed 14 articles on research of causes of delay (2002-2016) and found that $50 \%$ of them include "unqualified workers" and 36\% of them include "poor productivity of workers". Abebe [18] reviewed 24 surveys of causes of construction delays in 17 African countries (2010-2020) and found out that "low productivity of labor" and "shortage of skilled labor" were second ranked factors (each in 54\% of surveys), and "unqualified/inadequate experienced labor" was the sixth ranked factor (in 38\% of studies).

In these studies, questionnaires are mostly used for data collection and evaluation. The assessment of impact factors is usually from 1 to 5 , and the rank can be determined according to mean score (MS), relative importance index (RII), average index (AI), important weight (IW), severity index (SI), 
frequency index (FI), important index (IMP.I), etc. (The same factors are sometimes called differently in different studies).

Table 1 highlights the labor attributes, which in surveys in 41 different countries and parts of countries published in the last decade, are ranked as factors that affect the performance of construction projects (P), i.e., their delay (time overrun-T) and cost (C), with minimal uniformity of originally used terms. In order to better identify the significance and ratio of the magnitudes of individual factors, Table 1 contains, for each survey, the data of the respondents (project manager-Pm, project designer- $\mathrm{Pd}$, clients $-\mathrm{Cl}$, consultants- $\mathrm{Cns}$, and contractors $-\mathrm{Cnt}$ ), on the total number of evaluated factors (in relation to contractors) and the rank since they have different perceptions of the magnitude of the influence of individual factors.

Table 1. Influence of worker characteristics on the performance and goals of construction projects according to 55 chronologically arranged research papers. Construction projects $-\mathrm{P}$, time overrun- $\mathrm{T}$, cost $-\mathrm{C}$, project manager $-\mathrm{Pm}$, project designer $-\mathrm{Pd}$, clients $-\mathrm{Cl}$, consultants $-\mathrm{Cns}$, contractors $-\mathrm{Cnt}$.

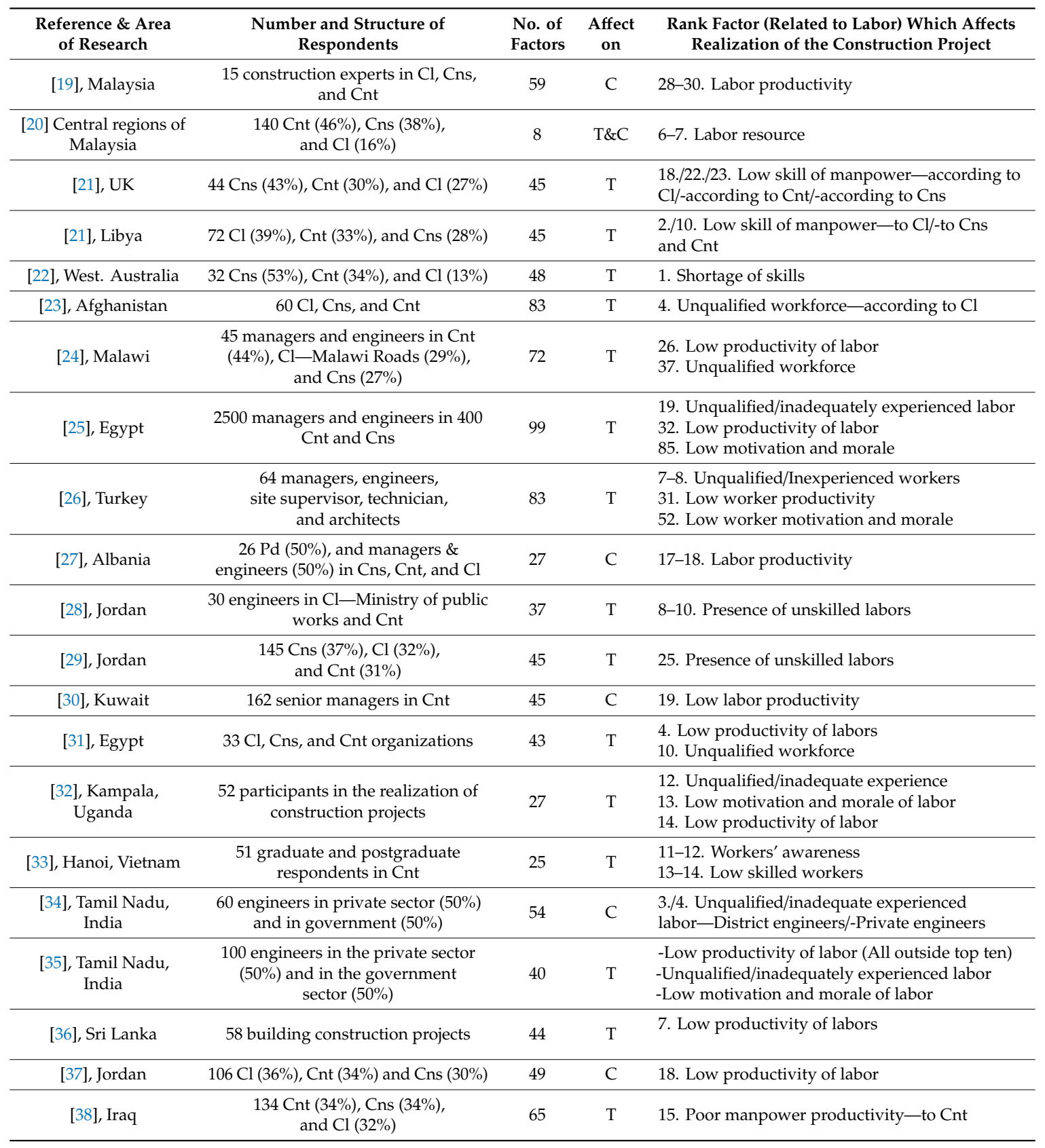


Table 1. Cont.

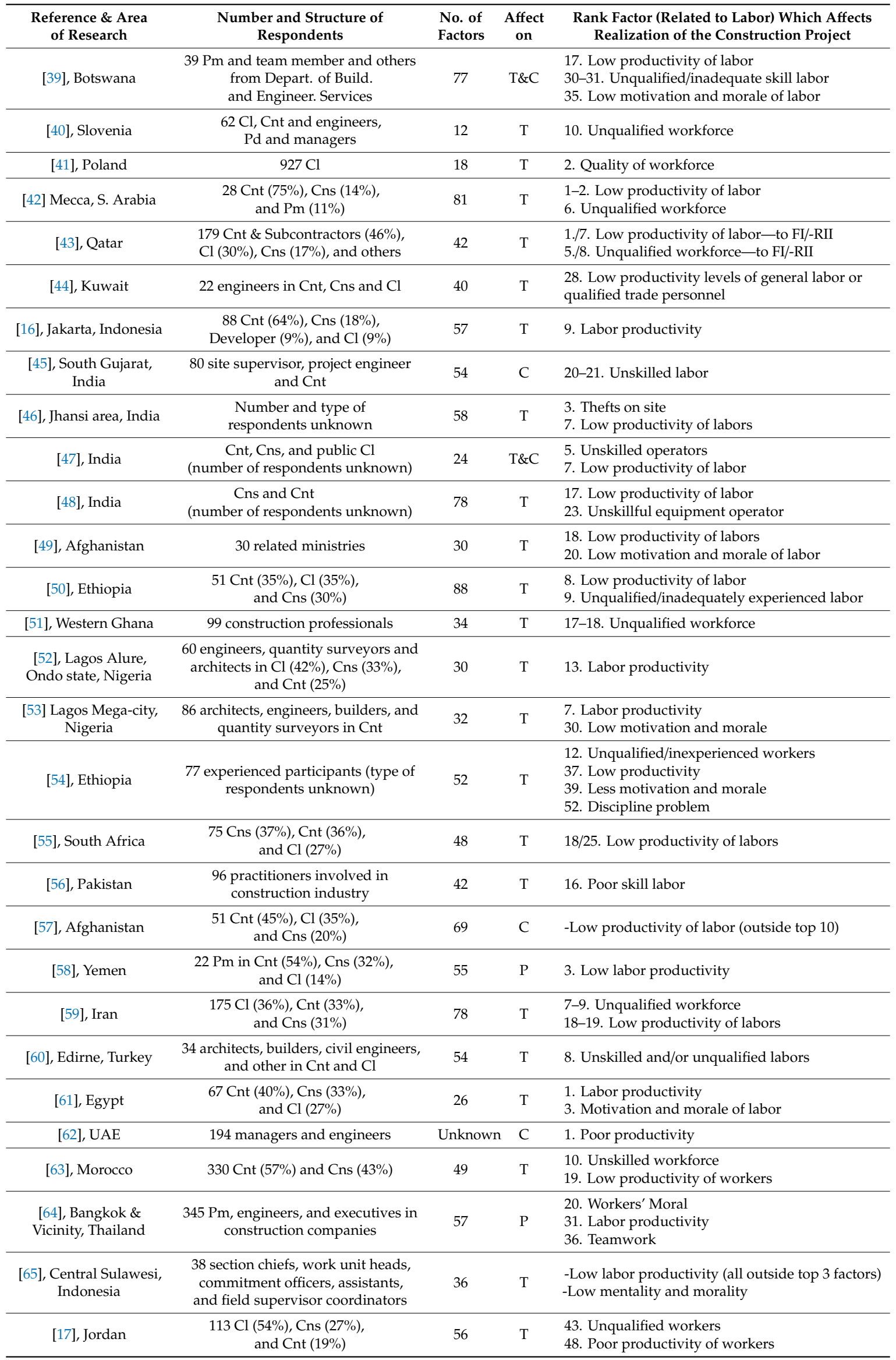


Table 1. Cont.

\begin{tabular}{|c|c|c|c|c|}
\hline $\begin{array}{l}\text { Reference \& Area } \\
\text { of Research }\end{array}$ & $\begin{array}{l}\text { Number and Structure of } \\
\text { Respondents }\end{array}$ & $\begin{array}{l}\text { No. of } \\
\text { Factors }\end{array}$ & $\begin{array}{l}\text { Affect } \\
\text { on }\end{array}$ & $\begin{array}{l}\text { Rank Factor (Related to Labor) Which Affects } \\
\text { Realization of the Construction Project }\end{array}$ \\
\hline $\begin{array}{l}\text { [66], Shan-Ewadh, } \\
\text { India }\end{array}$ & $\begin{array}{l}40 \text { Cnt, engineers, } \\
\text { different departments }\end{array}$ & 81 & $\mathrm{~T} \& \mathrm{C}$ & 3. Unskilled labors/labor strikes \\
\hline [67], South Korea & $\begin{array}{l}33 \text { BIM Cns }(33 \%), \mathrm{Cl}(18 \%) \text {, } \\
\text { Cnt }(15 \%) \text {, architects }(15 \%) \text {, } \\
\text { managers }(12 \%) \text {, and others }\end{array}$ & 34 & $\mathrm{~T}$ & 15. Low labor productivity \\
\hline $\begin{array}{l}\text { [68], South western } \\
\text { part of Nigeria }\end{array}$ & $\begin{array}{c}78 \text { engineers }(46 \%) \text {, quantity } \\
\text { surveyor }(23 \%) \text {, architects }(19 \%) \text {, } \\
\text { and builders }(12 \%)\end{array}$ & 12 & $\mathrm{C}$ & $\begin{array}{l}\text { 4./7-8. Low productivity of labor-Tendering } \\
\text { methods selective/-Competitive open }\end{array}$ \\
\hline $\begin{array}{l}\text { [69] Abuja, Lagos \& } \\
\text { Portharcourt, Nigeria }\end{array}$ & $\begin{array}{c}129 \text { Cnt \& Subcontractors }(47 \%), \\
\text { Site-engineers (19\%), Cns (17\%), } \\
\text { Pm }(9 \%) \text {, and Cl }(8 \%)\end{array}$ & 20 & $\mathrm{C}$ & 10. Low skilled manpower \\
\hline [70] Portugal & $\begin{array}{c}94 \mathrm{Cnt}(56 \%), \mathrm{Cns}(32 \%) \\
\text { and } \mathrm{Cl}(12 \%)\end{array}$ & 47 & $\mathrm{~T}$ & 10. Poor labor productivity and shortage of skills \\
\hline
\end{tabular}

In $65.5 \%$ of the research in Table 1, "labor productivity", which results from several attributes of workers, is included among the influential factors. In $56.4 \%$ of the research, the impact of skills/qualifications of the workforce was evaluated (in seven studies "experience" is also stated in addition to "skills"), and in $20.0 \%$ "morale/morality" (independently or with motivation). The established rank of the importance of labor productivity and the attributes of workers differ significantly, so, for example, "labor productivity" in the reviewed studies is ranked in the range of 1st to 48 th place.

Looking at the results of the studies, it can be seen that the impact of "labor productivity" on the performance of construction projects is greater in cases where:

- there are no other problems that interfere with the performance of works, or where there is good organization of performance (no shortages of materials, equipment, equipment failures, etc.),

- there are no problems with working conditions (extremely negative environmental impacts),

- there are no changes to the project during execution,

- there are no problems with the delay of payment for work performed, and

- $\quad$ there are no other problems with the investor or consultants.

\subsection{Characteristics of Workers Affecting the Construction Productivity}

Inconsistency of labor productivity is a severe problem in many countries. Therefore, labor productivity and factors affecting productivity has become one of the most regular topics for researchers $[1,2,71-76]$.

Borcherding [77] states that selection of workers is one of the factors that most influences productivity in large construction projects. Based on surveys of leading construction companies in Singapore, Alum and Lim [78] identified that hiring suitable workers is among the three most important factors affecting productivity. A survey by Mojahed and Aghazadeh [79] reveals that the skills and experiences of the workforce are the most influential factors for construction productivity on wastewater treatment plant projects in southern United States. Huang et al. [80] reviewed the literature and found that skilled labor availability is the most common influencing factor for productivity in U.S. construction. According to research by Inuwa [81] in Nigeria, adequate and competent workforce is a top-ranked measure for enhancing contractors' project planning.

In studies of the impact on productivity and performance of construction projects, factors are often divided into groups called "people", "workforce", "labor characteristics", etc. These groups include a number of attributes of workers and various other influences related to human resources (there is no uniformity in their definition). A comparative presentation of the relationship between the determined values of direct and indirect influences of the attributes of construction workers on labor productivity according to four research studies is given in Table 2 (research [76,82] shows only skill aspect factors). 
Table 2. Comparison of the extent of influence of workers' attributes researched in four previous papers (the mentioned ratios of magnitude influence were calculated from the data in published studies).

\begin{tabular}{|c|c|c|c|c|c|c|c|c|c|c|c|c|c|c|c|c|c|c|c|}
\hline Research & 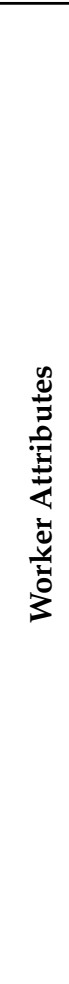 & 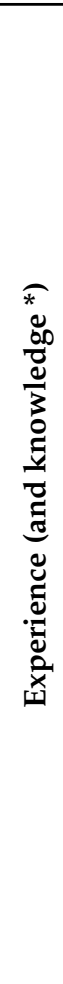 & 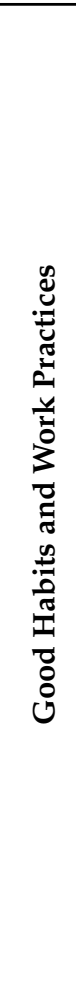 & 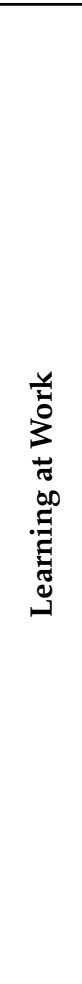 & 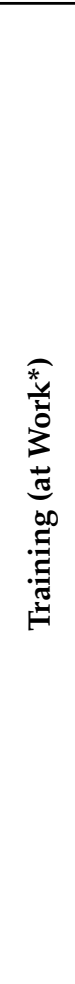 & 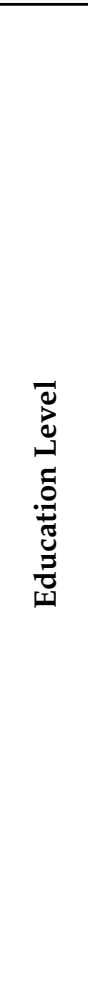 & $\underset{\pi}{\infty}$ & 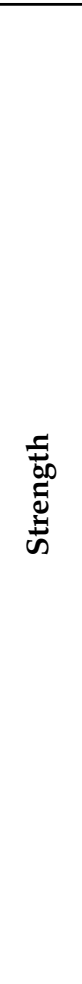 & 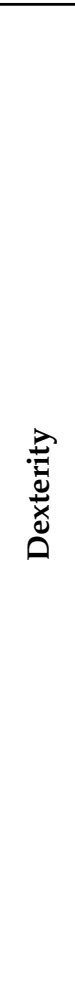 & 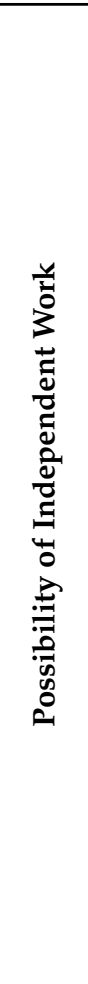 & 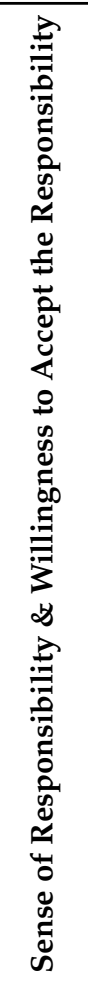 & 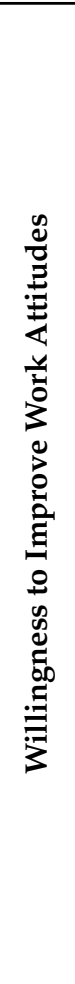 & 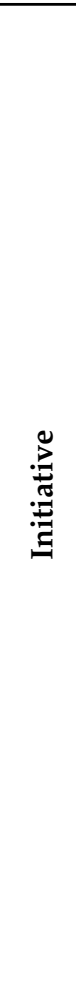 & 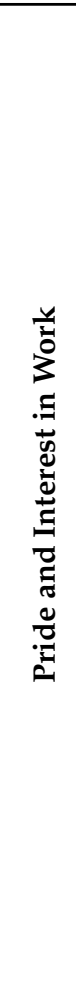 & 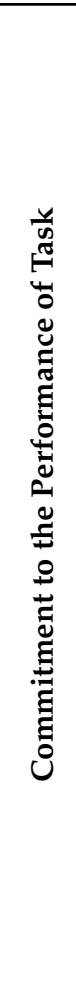 & 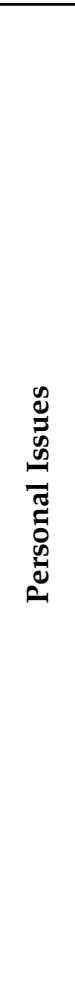 & 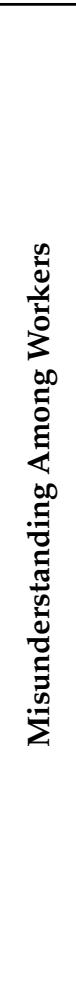 & 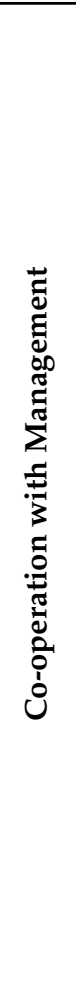 & 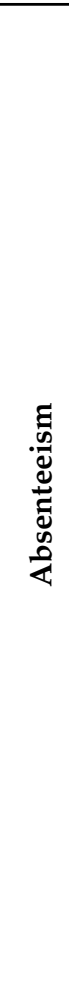 \\
\hline [82], UK & & 1.0 & & & 0.63 & & & 0.75 & 0.50 & & & & & & & & & & \\
\hline \multicolumn{2}{|c|}{ [83], Singapore } & & 0.95 & & & & & 0.86 & & & 1.0 & 0.94 & 0.84 & 0.90 & & & & 0.92 & \\
\hline \multicolumn{2}{|c|}{ [76], Malaysia * } & 1.0 & & 0.89 & 0.82 & 0.77 & & & & 0.94 & 0.93 & & & & 0.97 & & & & \\
\hline \multicolumn{2}{|l|}{ [84], India } & 1.0 & & & & & 0.83 & & & & & & & & & 0.50 & 0.65 & & 0.96 \\
\hline
\end{tabular}

* Only skill aspect factors (the influence of the group of factors "communication aspect" and "work culture aspect" was evaluated especially and "good interpersonal relationship between the workers" was ranked first, while "sharing knowledge and work information" and "attitude and behavior of people at the construction site" was ranked second). 
In a study of negative factors impacting productivity on construction sites in Croatia 35 years ago, Oštarijaš [85] singled out 9 basic factors, among which are poor characteristics of workforce-insufficient training of workers, alcohol consumption on construction sites, and smoking and rest at unforeseen times. According to the survey in the Czech Republic [86], the productivity of small construction companies is mostly influenced by training and experience of the workforce, while in medium and large companies it is the 5 th-8th factor (out of 17 factors).

Based on the scoring of results of 47 studies in 28 countries during the period 1983-2019, Hamza et al. [87] found that "worker efficiency/skills training" and "effectiveness/experience" of workers are 4th and 5th ranked factors according to construction labor productivity, while "personal problems" are 32nd-33rd ranked factors (out of 34 analyzed factors). Although the included studies examined the effects of different factors, some of them did not consider the characteristics of the workers at all.

In Table 3, the characteristics of different types of construction workers (craftsmen, auxiliary workers on site, equipment operators, and others) have been evaluated in research on the impact on construction productivity in the period from 2012 to 2020 in 44 different countries, regions within countries, and groups of countries on five continents. Part of the conducted research defines as an influential factor one or more characteristics of workers, while part of the research considers as an influential factor the absence of some of these characteristics (e.g., lack of skills, lack of training or inadequate training, poor health, etc.).

Table 3. Attributes of construction workers that affect productivity evaluated in previous research.

\begin{tabular}{cc}
\hline Labor (Worker/Craftsmen) Characteristics as Factors Influencing Productivity & Label \\
\hline Skills (level) & F1 \\
Quality of work/performance of labor & F2 \\
Occupational education level/training (technical knowledge) & F3 \\
Experience (level) & F4 \\
Age & F5 \\
Gender & F6 \\
Health & F7 \\
Strength and physical (fitness/ability) & F8 \\
Physical fatigue & F9 \\
Alcoholism & F10 \\
Addiction/drug abuse/similar problems & F11 \\
Personal issues (family problems, poor economic condition, etc.) & F12 \\
Loyalty & F13 \\
Job satisfaction & F14 \\
Workers' pride in their work & F15 \\
Habits & F16 \\
Discipline & F17 \\
Laziness & F18 \\
Commitment & F19 \\
Initiative & F20 \\
Team spirit among workers & F21 \\
Labor morale & F22 \\
Worker's integrity & F23 \\
Psychophysiological ability & F24 \\
Ability to adapt to changes and new environment & F25 \\
Sense of observance of regulations & F26 \\
\hline
\end{tabular}

Table 4 provides data on research that examined the impact of worker characteristics (listed in Table 3) on productivity and their impact rank, as well as the size of the impact index, i.e., indicator. 
Table 4. Ranking of the influence of the attributes of construction workers on productivity in the implementation of different types of construction projects in 55 chronologically arranged research. Construction projects $-\mathrm{P}$, time overrun $-\mathrm{T}$, cost $-\mathrm{C}$, project manager $-\mathrm{Pm}$, project designer $-\mathrm{Pd}$, clients- $\mathrm{Cl}$, consultants-Cns, contractors-Cnt.

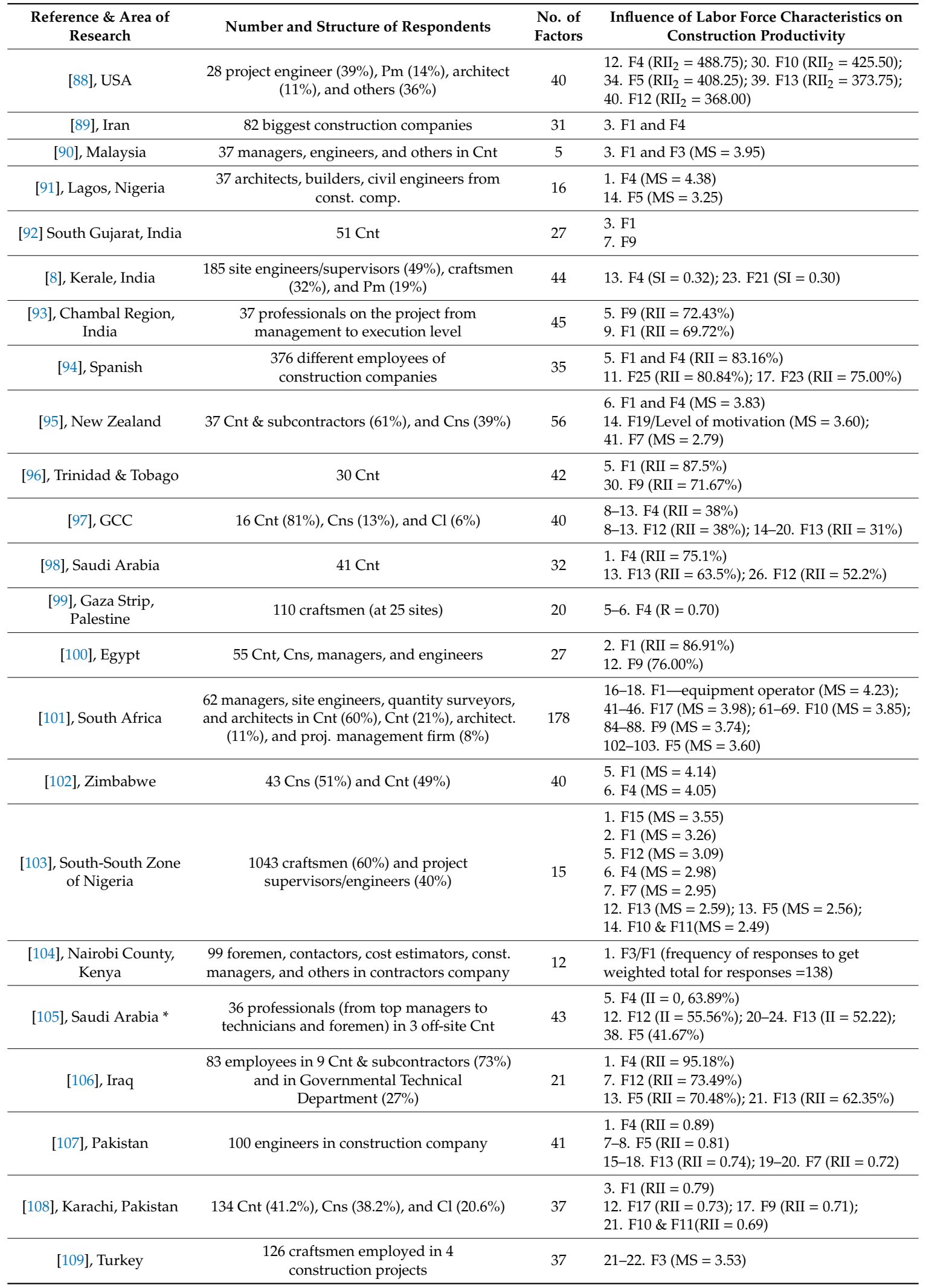


Table 4. Cont.

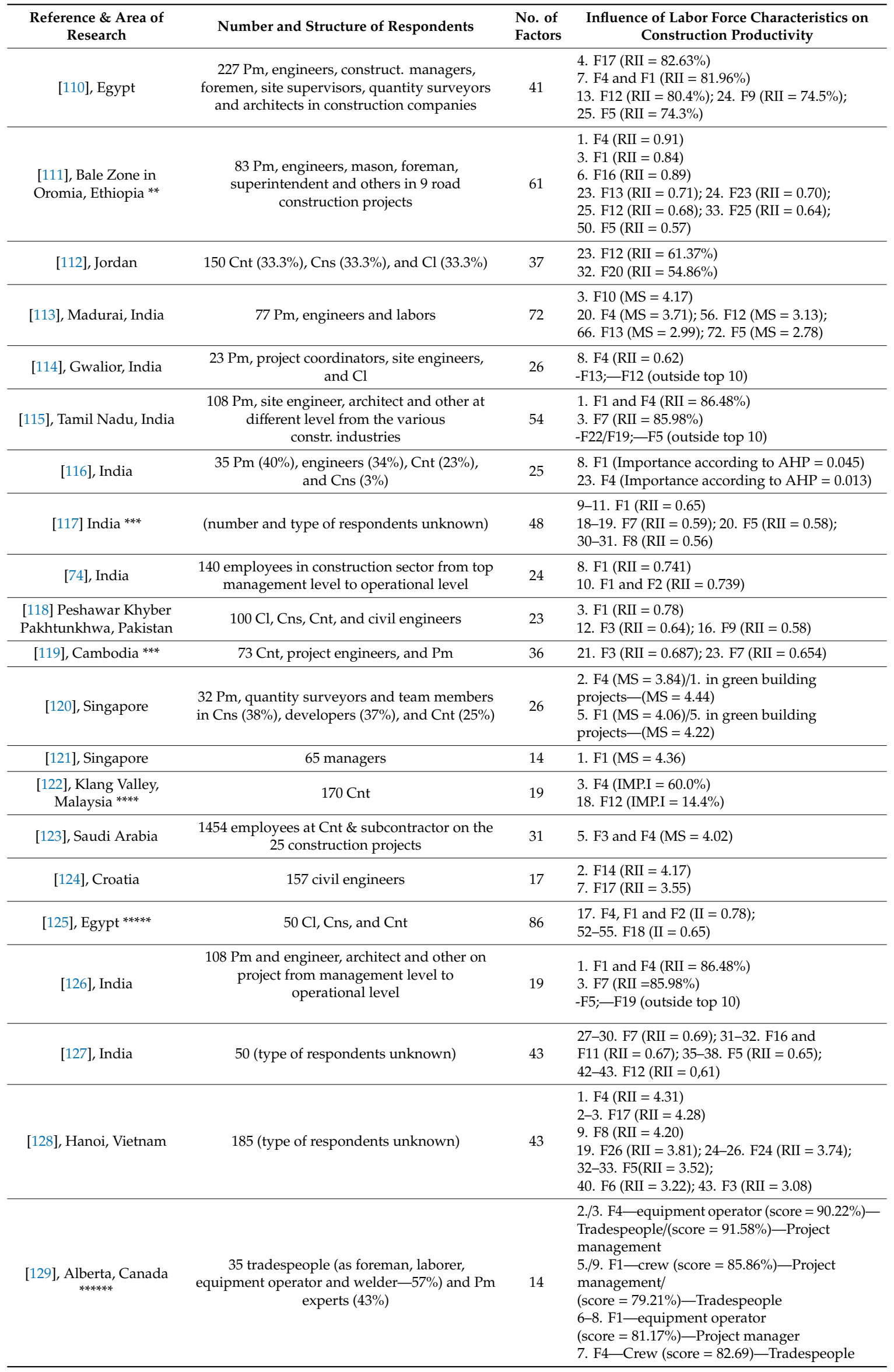


Table 4. Cont.

\begin{tabular}{|c|c|c|c|}
\hline $\begin{array}{l}\text { Reference \& Area of } \\
\text { Research }\end{array}$ & Number and Structure of Respondents & $\begin{array}{l}\text { No. of } \\
\text { Factors }\end{array}$ & $\begin{array}{l}\text { Influence of Labor Force Characteristics on } \\
\text { Construction Productivity }\end{array}$ \\
\hline [130], Poland & $\begin{array}{l}142 \text { craftsmen }(54 \%) \text { and engineers, managers, } \\
\text { directors, construction company owners, and } \\
\text { others }(46 \%)\end{array}$ & 17 & $\begin{array}{l}\text { 2. } \mathrm{F} 7(\mathrm{MS}=4.27) \\
\text { 3. } \mathrm{F} 9(\mathrm{MS}=4.18) \\
\text { 5. F5 }(\mathrm{MS}=3.83) \\
\text { 17. F8 }(\mathrm{MS}=3.09)\end{array}$ \\
\hline $\begin{array}{l}\text { [131], Iran and Lithuania } \\
\text { (for all) })^{* * * * * * *}\end{array}$ & 4 members of the project management team & 18 & $\begin{array}{l}\text { 4. F3 (fuzzy importance measures }=0.45 \% \text { ) } \\
\text { 10. F4 (fuzzy importance measures }=0.03 \% \text { ) }\end{array}$ \\
\hline [133], Yemen & $\begin{array}{l}91 \text { architectural and structural engineers } \\
\text { on construction projects }\end{array}$ & 52 & $\begin{array}{l}\text { 1. F4 and F1 }(\mathrm{RII}=88.6 \%) \\
\text { 28. F8 }(\mathrm{RII}=73.6 \%) ; 35 . \mathrm{F} 5(\mathrm{RII}=69.6 \%) \text {; } \\
\text { 52. } \mathrm{F} 3(\mathrm{RII}=58.4 \%)\end{array}$ \\
\hline [135], Maharashtra, India & 302 construction workmen & 29 & $\begin{array}{l}\text { 1. F12 }(\mathrm{RII}=55.4 \%) \\
\text { 13. } \mathrm{F} 9(\mathrm{RII}=47.6 \%) ; 16 . \mathrm{F} 13(\mathrm{RII}=47.1 \%) \text {; } \\
\text { 27. } \mathrm{F} 1(\mathrm{RII}=39.0 \%)\end{array}$ \\
\hline $\begin{array}{l}\text { [136], Ahmedabad, } \\
\text { Vadodara and } \\
\text { Gandhinagar, India }\end{array}$ & $111 \mathrm{Pm}$ and site engineers & 72 & 4. $\mathrm{F} 1(\mathrm{RII}=0.78)$ \\
\hline $\begin{array}{l}\text { [137], Khulna city, } \\
\text { Bangladesh }\end{array}$ & $100 \mathrm{Cl}$, engineers, $\mathrm{Cnt}$, and subcontractors & 15 & 2. $\mathrm{F} 1(\mathrm{RII}=0.81)$ \\
\hline [138], Libya & $76 \mathrm{Cns}$, Cnt, managers, and engineers & 30 & $\begin{array}{l}\text { 2. F4 and F1 }(\mathrm{RII}=0.87) \\
\text { 18. F9 }(\mathrm{RII}=0.65)\end{array}$ \\
\hline
\end{tabular}

Labor Productivity in: * off-site construction; ${ }^{* *}$ road construction projects; ${ }^{* * *}$ residential building projects; ${ }^{* * * *}$ non-residential projects; ${ }^{* * * *}$ pre-stressed concrete bridges; ${ }^{* * * * *}$ equipment-intensive activities; ${ }^{* * * * * * *}$ high-rise building; ${ }^{* * * * * * *}$ precast bridge construction.

It can be seen that the studies involving factors affecting productivity often include those attributes of labor that have been considered in other studies (in Table 1) and that affect performance and delays and cost overrun in construction projects as to the goals of realization of construction projects. Tables 1-3 and Table 5 confirm the finding of previous literature reviews [141] that research differs in the structure of the study (surveys) and in evaluation of the importance of influencing factors.

According to 55 studies included in Table 4, "skills" and "experience" were the most frequently evaluated characteristics of workers and were rated as the most important in terms of impact on productivity. The number of considerations and the assessed importance for the most significant characteristics in the studies from the Table 4 are presented in Figure 2. The importance was determined by the score for the ten first-ranked factors in each study (so the first-ranked received 10 points and the tenth-ranked received 1 point) divided by the maximum possible score, i.e., $55 \times 10$ (e.g., for "skills" $190 / 550 \times 100=36.2 \%$ ). Frequency percentage was calculated as the ratio of the number of studies in which a certain characteristic is evaluated (regardless of rank) and the total number of studies reviewed (e.g., for "experience" $34 / 55 \times 100=61.8 \%$, for "skills" $32 / 55=58.2 \%$, etc.).

The Mechanical Contractors Association of America has published over the years a number of factors that affect labor productivity in the U.S., and since the 1970s their list of "factors affecting productivity" includes "morale" [142]. In the analyzed studies, morale is considered more often in studies of impact on time and performance than in studies of the impact on productivity. Horner and Witehead [82] define morale as a separate factor influencing labor productivity, and do not show how much more morale influences worker skills compared with the influences of other worker characteristics (listed in Table 2). According to [82], morale is rated in terms of good humor, cooperative attitude, 
pride in work, good timekeeping, and complaints, all equally weighted. Such an interpretation is closely related to management action and employee motivation. In addition to denoting the level of enthusiasm, morale (in Croatia) is also defined as a set of social norms associated with behavior according to the principles of honesty and integrity, i.e., morality. A number of studies on impacts on labor productivity do not directly mention worker morality, but moral-related traits (e.g., integrity, theft, and general behavior).

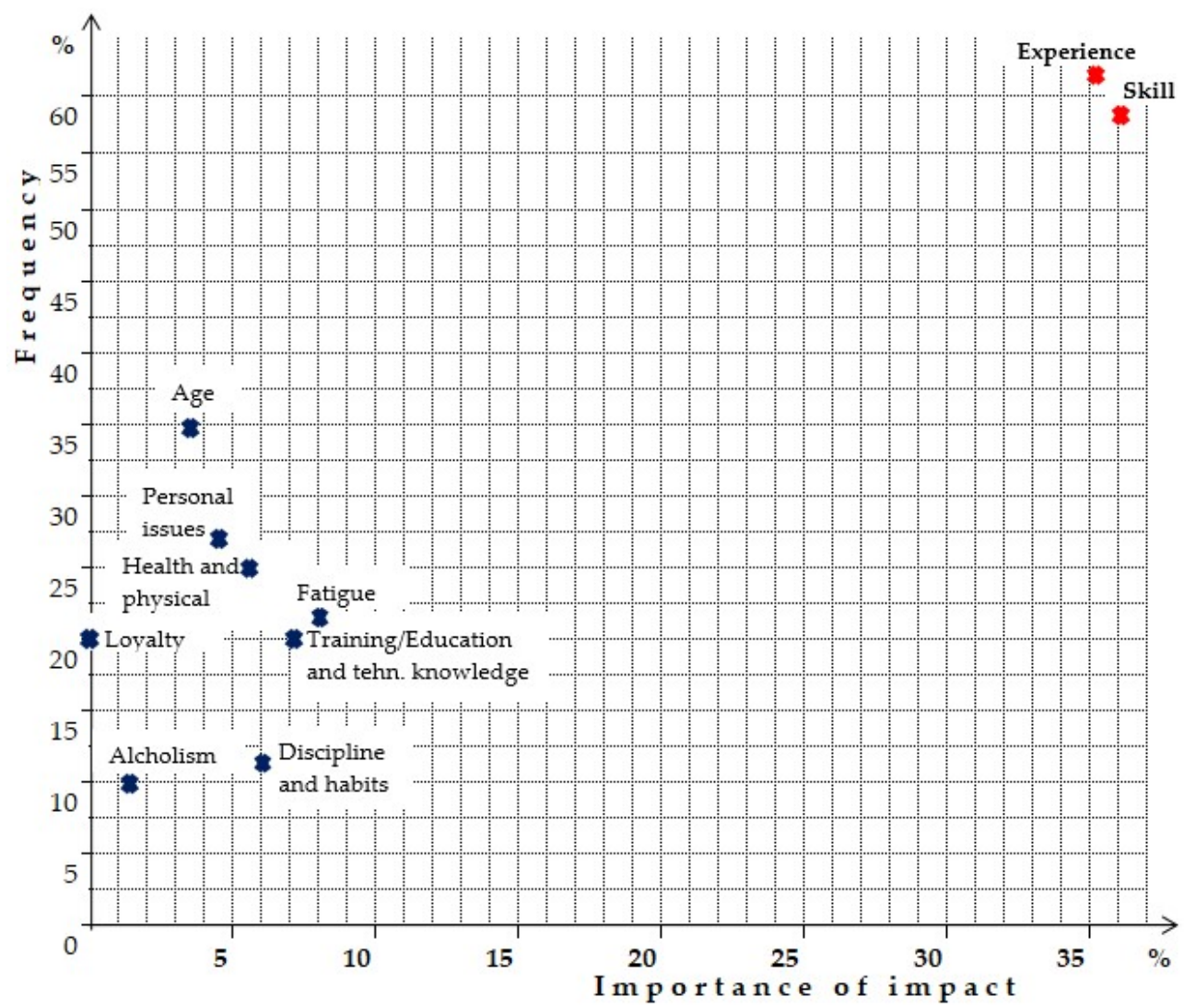

Figure 2. Frequency and importance of attributes of labor determined in all studies from Table 4.

Table 5. Factors associated with labor that are under the dominant influence of management and other factors.

\begin{tabular}{|c|c|}
\hline Influenced Factors & $\begin{array}{c}\text { Studies on Impacts on Project Performance and } \\
\text { Contractor Productivity }\end{array}$ \\
\hline Shortage of skilled and/or experienced labor & $\begin{array}{c}{[7,16,21,37,52,53,62,70,80,92,93,96,100,101,104,105} \\
112,117,119,125,136,143-155]\end{array}$ \\
\hline Lack of training or level of training & $\begin{array}{c}{[62-64,95,96,102,105,114,115,117,121,128,131,132,134,} \\
137,148,156-158]\end{array}$ \\
\hline $\begin{array}{l}\text { Absenteeism/late arrival, early quit, } \\
\text { and frequent unscheduled breaks }\end{array}$ & $\begin{array}{c}{[8,14,16,19,25,34,45,53,65,84,88,91,95,98,99,102-105} \\
107,108,110-113,115,119,122,123,126,127,129,130,133 \\
135,145,159]\end{array}$ \\
\hline $\begin{array}{l}\text { Lack of respect and personal } \\
\text { relationsbetween workmates }\end{array}$ & $\begin{array}{c}{[17,25,35,48,57,59,98,99,105,106,111-113,115,116,122-} \\
124,132,160-162]\end{array}$ \\
\hline
\end{tabular}

Quite a number of research papers have identified the importance of some other factors that are closely related to the personal attributes of workers as influential on the performance of construction projects and influences on labor productivity. However, these factors are strongly influenced by 
company management, social environment, and the labor market in various ways. These factors, and corresponding research that evaluated their impact, are listed in Table 5.

Absence from work and late arrival, early departure, and frequent unnecessary breaks outside the planned schedule significantly depend on discipline, work habits, competition and morale of workers, as well as on supervision and motivation (reward or punishment) by the management of contractor.

Many studies have identified motivation as a factor related to the workforce with a significant impact on productivity. However, it has not been considered in this study because, although it depends on the needs and preferences of individuals $[163,164]$, apart from intrinsic motivation, motivation of workers primarily depends on competent management. (Thus, for example, the same worker may be motivated and productive in one company and not in another).

\section{Investigation of the Influence Attributes of Construction Workers on Productivity in Croatia}

\subsection{Objectives, Scope and Methodology of the Research}

The main objectives of this research include the following:

- To identify the influence of construction worker attributes on contractors' labor productivity in Eastern Croatia (i.e., Slavonia and Baranja region).

- To determine the relationship between worker attributes and other factors that affect productivity.

- To quantify the influence of the possession and absence of important characteristics of workers on labor productivity in Slavonia and Baranja.

- To test the relevance of the assessed importance of worker characteristics by comparing the rankings of the characteristics between two different groups of respondents.

- To identify general actions that can be taken to influence the considered attributes of workers in order to increase contractor productivity.

The research was performed through the steps shown in Figure 3.

\subsection{Defining the Attributes of Workers to Examine the Influence on Labor Productivity}

Based on the literature review, a list of worker characteristics that affect productivity was compiled. This list was further reviewed and updated through semi-structured interviews with seven civil engineers and one technician, who had more than 25 years of experience working with construction workers. Positive and negative impacts on the productivity of construction contractors resulting from a possession of higher level of labor characteristics or lack of labor characteristics (along with the action of other factors) selected for the survey were defined. This is shown in Table 6.

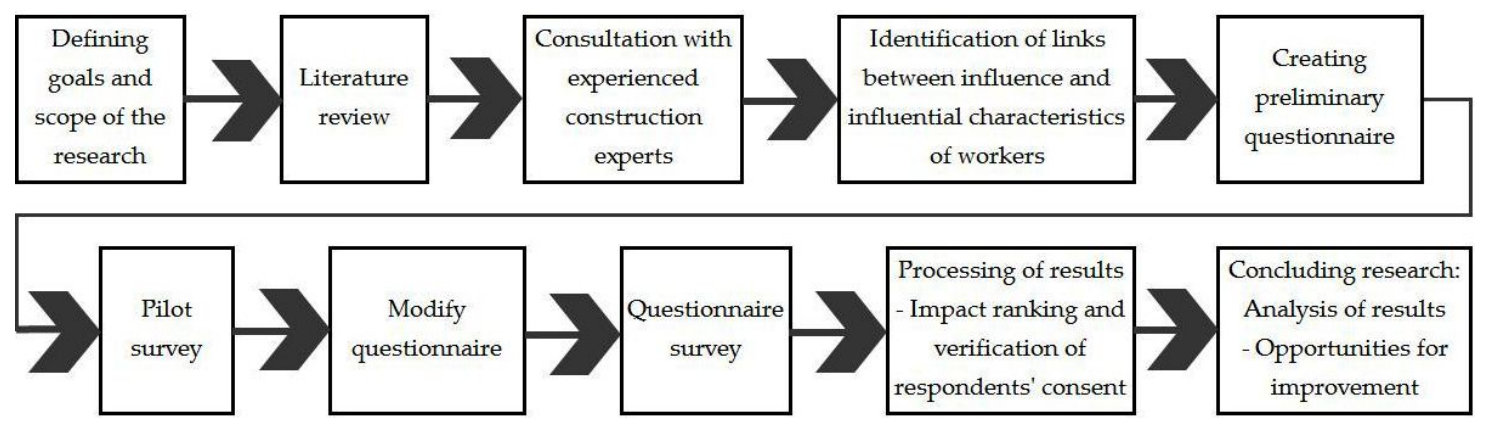

Figure 3. Flow chart of research in Croatian regions Slavonia and Baranja. 
Table 6. Worker attributes and positive and negative effects on labor productivity in case the attributes are better or worse.

\begin{tabular}{|c|c|c|c|c|}
\hline Positive Effects on Productivity & $\begin{array}{l}\text { Low } \\
\text { Level }\end{array}$ & $\begin{array}{c}\text { Considered Workers' } \\
\text { Characteristics }\end{array}$ & $\begin{array}{l}\text { High } \\
\text { Level }\end{array}$ & Negative Effects on Productivity \\
\hline $\begin{array}{l}\text { Physical durability-faster } \\
\text { realization of work tasks }\end{array}$ & $\leftarrow$ & $\begin{array}{l}\text { Strength, dexterity, } \\
\text { and Education }\end{array}$ & $\rightarrow$ & Physical fatigue—slow work, \\
\hline $\begin{array}{l}\text { Good skills-flexibility (a wider } \\
\text { range of action), quality } \\
\text { performance, faster realization of } \\
\text { work tasks, independent work } \\
\text { action, working in a safe way }\end{array}$ & $\leftarrow$ & $\begin{array}{l}\text { Education and experience, } \\
\text { dexterity, creativity }\end{array}$ & $\rightarrow$ & $\begin{array}{c}\text { Lack of skills-small area of } \\
\text { operation, operating errors } \\
\text { (rework), slow work, } \\
\text { non-independence in } \\
\text { work, injuries }\end{array}$ \\
\hline $\begin{array}{l}\text { Adaptability to new conditions } \\
\text { at work }\end{array}$ & $\leftarrow$ & $\begin{array}{l}\text { Adaptability to new } \\
\text { conditions and situations } \\
\text { (creativity and dexterity) }\end{array}$ & $\rightarrow$ & $\begin{array}{l}\text { Inadaptability to new conditions } \\
\text { at work }\end{array}$ \\
\hline $\begin{array}{l}\text { Good work habits and discipline, } \\
\text { honesty, integrity, sense of } \\
\text { responsibility, compliance } \\
\text { with orders }\end{array}$ & $\leftarrow$ & Morale and morality & $\rightarrow$ & $\begin{array}{l}\text { Absenteeism/late arrival, early quit } \\
\text { and frequent unscheduled breaks, } \\
\text { theft, negligence, alcoholism }\end{array}$ \\
\hline $\begin{array}{l}\text { Good interpersonal relationships, } \\
\text { work atmosphere and cooperation }\end{array}$ & $\leftarrow$ & $\begin{array}{l}\text { Affinity for teamwork } \\
\text { (morale and morality) }\end{array}$ & $\rightarrow$ & $\begin{array}{l}\text { Bad relations with coworkers, } \\
\text { weak cooperation }\end{array}$ \\
\hline
\end{tabular}

For the analysis of various influential characteristics, an Ishikawa chart was compiled with a focus on the influence of the labor on the productivity of construction contractors (Figure 4).

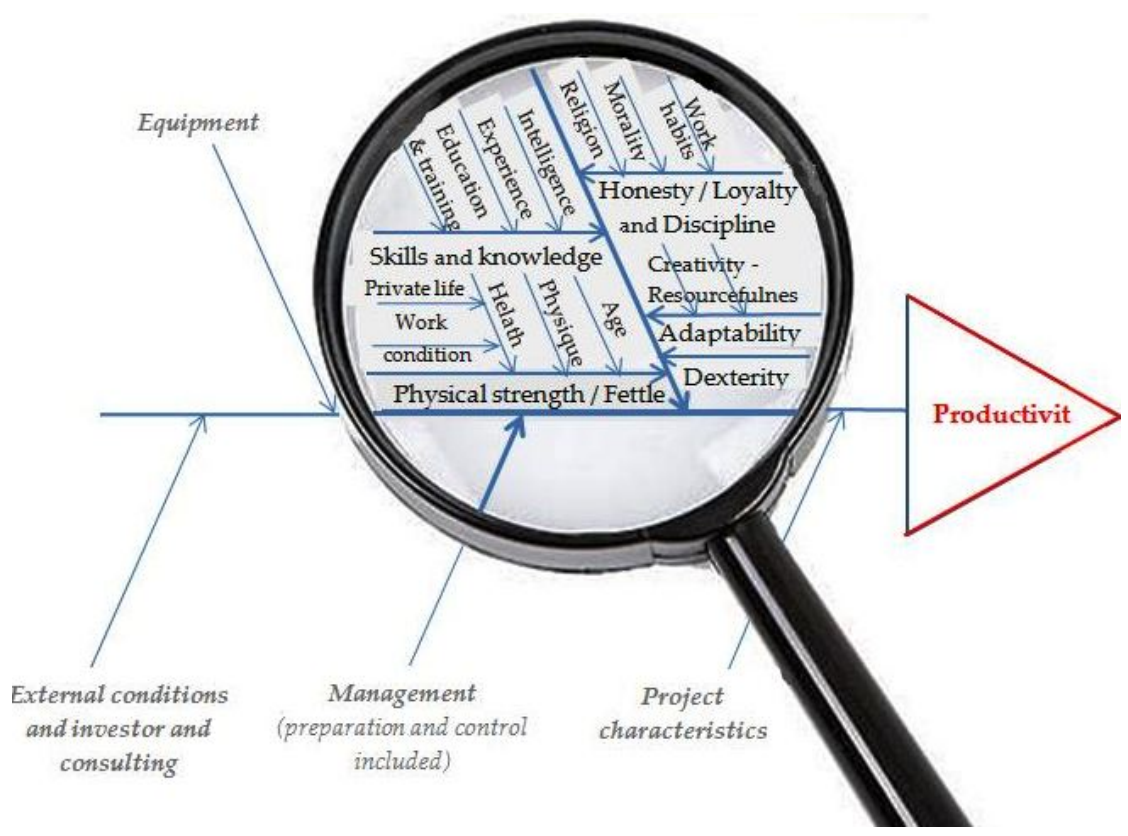

Figure 4. Workforce on Ishikawa chart of effects on contractor's productivity.

The consulted experts in Croatian practices emphasized the importance of independence in the work of construction workers, with additional desirable properties being the willingness to take initiative and responsibility. This is enabled by technical skills that arise from professional knowledge, i.e., training and experience.

For this research, workers' attributes that were comparable to previous surveys and that were not interdependent were selected. Physical strength was taken as one of the examined characteristics because a recent analysis by Karthik and Rao [165] showed a significant correlation between physical strength and productivity of construction labor. However, the age and health of the workers were not taken into consideration, even though physical strength is dependent on these parameters. Fatigue is 
related to the physical characteristics of workers, but it largely depends on the technology and organization of work (rest schedule, etc.), and therefore has not been examined in the survey. Some of the workers' attributes mentioned in the literature (surveys included in Tables 1-4) were not included in this research in Croatia for the reasons listed in Table 7.

Table 7. Workers' attributes not covered by this research.

\begin{tabular}{|c|c|}
\hline Characteristics Omitted from the Survey & Reason for Omission \\
\hline $\begin{array}{l}\text { Loyalty, relations between workmates and superiors, diligence, } \\
\text { obedience, job satisfaction, discipline and work habits, sense of } \\
\text { responsibility, willingness to learn, willingness to improve work } \\
\text { attitudes, willingness to perform overtime and shift work }\end{array}$ & $\begin{array}{l}\text { Under the strong influence of other } \\
\text { factors (largely depends on the } \\
\text { company, or the actions of management) }\end{array}$ \\
\hline $\begin{array}{c}\text { Intrinsic motivation, personal issues, love of job, proactivity, } \\
\text { sense of responsibility, ability to adapt to changes and } \\
\text { new environments }\end{array}$ & $\begin{array}{l}\text { It is difficult to assess the impact of } \\
\text { such testing }\end{array}$ \\
\hline Health, alcoholism, the sense of observance of regulations & It must be within the regulations \\
\hline Carefulness, diligence, resourcefulness, honesty, religion & $\begin{array}{l}\text { Not comparable with the results of } \\
\text { other research }\end{array}$ \\
\hline
\end{tabular}

After the pilot survey of 20 construction workers and engineers, 3 characteristics of the workers whose influence was assessed to be the least were excluded from further research- "creativity", "adaptability" (to new conditions/situations at work), and "affinity for teamwork". Furthermore, these three characteristics cannot be compared with the results of the research in Table 2. "Affinity for teamwork" and "adaptability" on average had values similar to some of the left out characteristics, so they can be taken into consideration again in future research.

Through the survey, it was possible for the respondents to suggest characteristics that were not listed, but that they considered to be important for labor productivity. None of the proposals were accepted since they were not justifiable. This fact, together with the high marks obtained for the impact of the examined characteristics, shows that the examination covered all important attributes of workers.

\subsection{Ranking the Influence of Workers' Characteristics by Survey}

Data collection was performed using survey questionnaires that were given directly to the respondents (face to face). In the survey, grades 1 to 5 (Likert scale) were used to assess in parallel the positive impact of personal characteristics of workers on labor productivity and the negative impact in the case that these characteristics are weak or absent. (This is because some characteristics can have a very positive effect on productivity, but if their absence can be well compensated, they do not necessarily have the same negative effect). The collected responses were based on respondents' knowledge and experience and were not related to any particular building project.

The magnitude and rank of the impact were determined by the RII method, according to the equation $[8,30,78,133]$ :

$$
\mathrm{RII}=\frac{5 n_{1}+4 n_{2}+3 n_{3}+2 n_{4}+n_{5}}{5\left(n_{1}+n_{2}+n_{3}+n_{4}+n_{5}\right)}
$$

where:

$n_{1}$-the number of respondents who answered "very strong influence" (rated with 5),

$n_{2}$-the number of respondents who answered "strong influence" (rated with 4),

$n_{3}$-the number of respondents who answered "medium influence" (rated with 3),

$n_{4}$-the number of respondents who answered "weak influence" (rated with 2), and

$n_{5}$-the number of respondents who answered "very weak influence" (rated with 1). 
Impact assessments were collected by examining 290 participants in the implementation of construction projects, employed in 60 companies for construction and supervision of construction projects in Slavonia and Baranja. A total of 28 completed questionnaires were rejected due to incorrectly completed questionnaires and inadequate profession and very few years of practice. Finally, a total of 262 completed questionnaires were analyzed.

Considering the 12,300 employees in the construction industry in Slavonia and Baranja (about 13\% of construction workers in the whole of Croatia) [166], 262 answered questionnaires provide a confidence interval of $6 \%$.

Correlation and descriptive research require at least 30 respondents in each group [167], so for the analysis, the answers of the respondents were divided according to the work they perform:

- Group A-supervising engineers and management of construction sites and construction companies and crafts,

A1-supervising engineers (authorized supervising and members of the supervisory team), and A2-construction site management (headman and other engineers and construction technicians), management and owners of construction companies and crafts.

- Group B-workers at the construction site,

B1-gang foreman and workers of various construction occupations (masons, carpenters, reinforcement workers, roofers, painters, and installers),

B2-site mechanization operators and drivers in construction companies, and

B3-auxiliary workers on the construction site (only with 5 and more years of practice in construction).

Figure 5 shows the percentages of respondents according to the jobs they were engaged in and their average years of experience in construction practice. The ratio of respondents from group A and group B was $37 \%$ to $63 \%$. Supervising engineers had the most years of work in construction practice on average, and auxiliary workers the least.

\subsection{Results of Surveys}

The survey results for all groups of respondents are processed in Table 8. The magnitudes of the positive and negative effects of the examined characteristics of workers on productivity according to the assessments of all respondents are shown in Figure 6.

According to RII values, the positive impact on productivity of "experience in construction" and "dexterity" is very high (RII $>0.80)$. All other assessed influences were high $(0.60 \leq \mathrm{RII}<0.80)$. The order of magnitude of the positive impact of good worker traits on labor productivity is similar to the order of magnitude of the negative impact on productivity if those traits are lacking. Spearman's rank correlation coefficient between positive and negative influence is $r_{\underline{s}^{\prime}}=0.8$, (a very good correlation between the rank of positive and negative action is when $\mathrm{r}_{\underline{s}^{\prime}}>0.76$ [168].) On average, according to all respondents, the positive impact of possession of all assessed characteristics is greater than the negative impact due to their absence (from $16.4 \%$ to $40.2 \%$ ). The most pronounced difference is the magnitude of the positive and negative impact of the worker's experience, which shows that respondents believe that the lack of experience can be compensated in some way (such as including an experienced worker next to inexperienced workers). The smallest difference between a positive impact and a negative impact is related to workers morale/morality (since the lack of this characteristic cannot be compensated). 


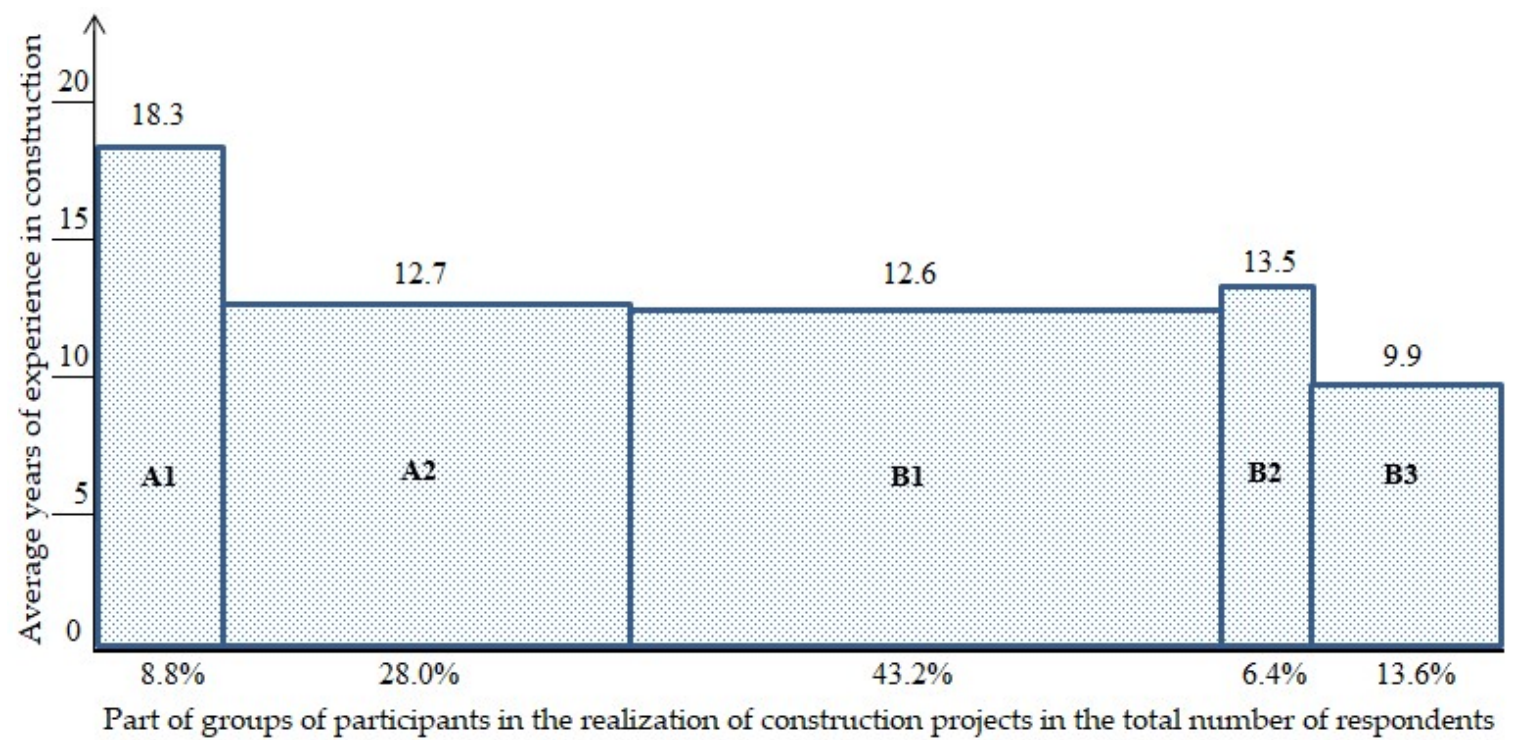

Figure 5. The percentages of groups of respondents and the average years of experience in construction.

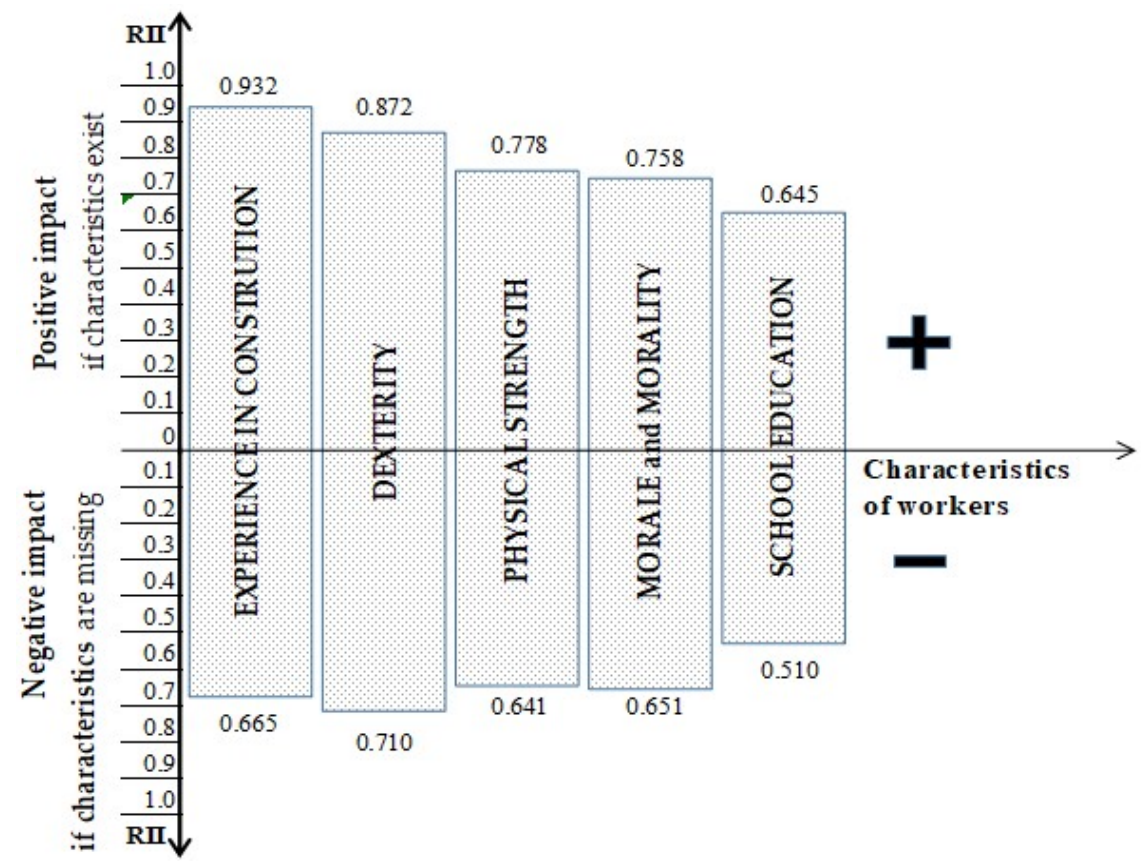

Figure 6. Characteristics of workers ranked by the magnitude of the impact on labor productivity according to the opinion of all respondents.

Table 8 shows that all groups of respondents also rank the first two characteristics according to the positive impact on productivity, and only supervising engineers do not rate school education as having the weakest impact. The degree of agreement in ranking the impact of worker characteristics by different groups of respondents was also expressed using Spearman's rank correlation. All groups of workers (B1, B2, and B3) also ranked all characteristics of workers according to the positive impact $\left(r_{s^{\prime}}=1.0\right)$. When evaluating the positive impact of the characteristics of workers from group $A$ and group B (the same order was obtained for the whole group A as for group A2 because there were three times more respondents in group $\mathrm{A} 2$ than in A1), $\mathrm{r}_{\mathrm{s}^{\prime}}=0.9$, which means that there was an excellent correlation, i.e., agreement. The rank of negative influence due to the absence of evaluated characteristics from group A (same for A2) and B was $r_{\mathrm{s}^{\prime}}=0.55$, which means that there was a medium-strong and positive relationship $\left(r_{s^{\prime}}>0.5\right.$ [168]) between the grades of these two groups of 
respondents. Due to this agreement in ranking by different groups of respondents, the results of this study can be considered reliable.

Table 8. The rank of importance of workers' characteristics by groups of respondents.

\begin{tabular}{|c|c|c|c|c|c|c|c|c|c|c|}
\hline \multirow{2}{*}{$\begin{array}{l}\text { Attributes of Workers } \\
\text { Presence of attribute }\end{array}$} & \multicolumn{2}{|c|}{ A1 } & \multicolumn{2}{|c|}{ A2 } & \multicolumn{2}{|c|}{ B1 } & \multicolumn{2}{|c|}{ B2 } & \multicolumn{2}{|c|}{ B3 } \\
\hline & RII & Rank & RII & Rank & RII & Rank & RII & Rank & RII & Rank \\
\hline $\begin{array}{l}\text { Experience in } \\
\text { construction }\end{array}$ & 0.945 & 1. & 0.918 & 1. & 0.915 & 1. & 0.975 & 1. & 0.888 & 1. \\
\hline School education & 0.654 & 4. & 0.662 & 5. & 0.624 & 5. & 0.738 & 5. & 0.624 & 5. \\
\hline Dexterity & 0.836 & 2. & 0.903 & 2. & 0.872 & 2. & 0.887 & 2. & 0.824 & 2. \\
\hline Physical strength & 0.609 & 5. & 0.729 & 4. & 0.831 & 3. & 0.862 & 3. & 0.782 & 3. \\
\hline Morale/morality & 0.718 & 3. & 0.863 & 3. & 0.698 & 4. & 0.750 & 4. & 0.759 & 4. \\
\hline \multicolumn{11}{|l|}{ Absence of attribute } \\
\hline $\begin{array}{l}\text { Experience in } \\
\text { construction }\end{array}$ & 0.682 & 1. & 0.646 & 3. & 0.664 & 2. & 0.700 & 3. & 0.677 & 2. \\
\hline School education & 0.481 & 5. & 0.523 & 5. & 0.491 & 5. & 0.625 & 5. & 0.506 & 5. \\
\hline Dexterity & 0.655 & 2. & 0.677 & 2. & 0.744 & 1. & 0.737 & 2. & 0.688 & 1. \\
\hline Physical strength & 0.536 & 4. & 0.600 & 4. & 0.672 & 3. & 0.775 & 1. & 0.629 & 4. \\
\hline Morale/morality & 0.600 & 3. & 0.714 & 1. & 0.615 & 4. & 0.637 & 4. & 0.676 & 3. \\
\hline
\end{tabular}

The overall assessment of the consistency of the opinions of the respondents of all groups was determined using the Kendall coefficient. A maximum of 1 means complete disagreement, and 0 means that there is a complete match [168]. A value of 0.11 for this coefficient was obtained for the answers on the positive impact of worker traits, and 0.05 for the negative impacts of the lack of traits. These values indicate a high level of agreement of all respondents on the impact on labor productivity.

\section{Discussion on Research Results and Improvement of Important Worker Attributes}

\subsection{Comparison of Research Results in Croatia and in Previous Research}

In the Croatian regions of Slavonia and Baranja, the "experience" of construction workers was considered the most important factor for labor productivity, similar to what was obtained in the studies of Horner and Witehead [82] in the UK, Tammy et al. [76] in Malaysia, and Jain et al. [84] in India. A study by Lim [83] in Singapore showed that "good habits and work practices" have a second-ranked impact. In this research, "sense of responsibility", which is related to employee morale, was rated the most important for improving productivity, and the positive impact of morale/morality was ranked fourth (very close to the third ranked impact) in research in Slavonia and Baranja. In this research, the impact of "physical strength" was rated one rank lower than in the research of Horner and Witehead [82]. However, in the UK, "dexterity" was rated the least important for workers' skills and labor productivity, and in Slavonia and Baranja its positive impact was ranked as second, while for the lack of worker skills, respondents considered it to have the most negative impact. It can be assumed that the reason for this is the greater need for improvisation due to the presence of poorer equipment on construction sites in Croatia than equipment in the UK.

From the workers' characteristics in Slavonia and Baranja, "school education" has the least impact on labor productivity (the positive impact of experience is $44 \%$ higher), as in the research of Tammy et al. [76] (in which experience was rated close to 30\% more important) and Horner and Witehead [82] (in which experience was rated 60\% more important). Tammy et al. (2019) have especially emphasized the greater importance of "learning and training at work" rather than "education level" [76]. The lack of skills in Slavonia and Baranja was rated 39\% more negative for productivity than the lack of school education. 


\subsection{The Possibility of Improving Contractor Productivity through Labor Force Attributes}

The results of this research in Croatia indicate the priorities of certain workers' characteristics that need to be addressed in order to increase productivity. In order to identify possible ways to improve productivity through the labor force attributes, it is necessary to determine which attributes directly and indirectly affect productivity and which factors affect these attributes. The ability of workers consists of mental and physical activities and knowledge [169]. Figure 7 defines the flow of action and impact on the ability and willingness to work of workers, both of which, together, determine labor productivity [170].

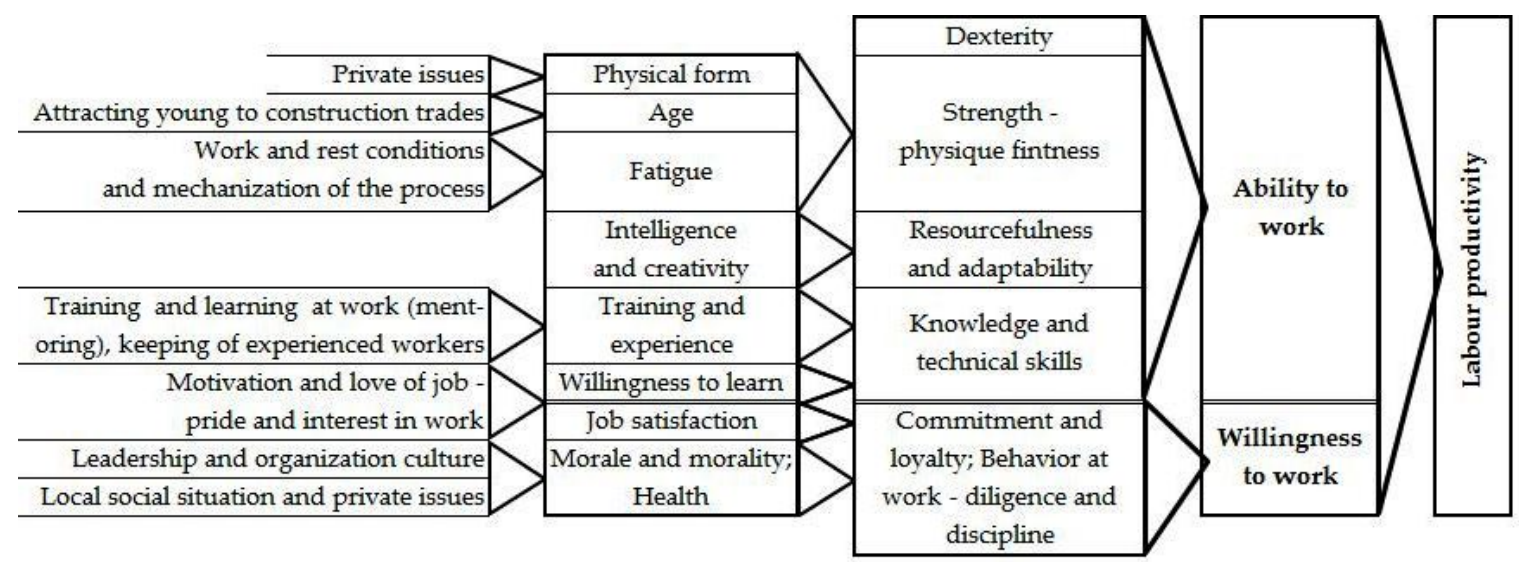

Figure 7. The order-related effects on labor productivity.

The employers cannot significantly influence some attributes of workers, but they should certainly take them into account when hiring and choosing workers for a particular job. In addition, it is possible for contractor management to act through:

- Leadership, appropriate supervision of workers, organization of work on the construction site (conditions for work and rest), incentive programs and development of the organization's culture;

- On-the-job training (with incentives to acquire new competencies) and an internal mentoring system for under-trained workers; and

- Recognizing and retaining existing quality, experienced workers, and attracting young, quality workers.

The employer often does not have much choice when hiring construction workers, but it is important to recognize those workers who have desirable characteristics while working with employees and try to encourage them to transfer those characteristics to other workers. A continuous and consistent business policy with personalized measures is needed to maintain employee satisfaction, at least to the extent of satisfying their extrinsic (hygienic) motivational factors (i.e., avoiding dissatisfaction that would prevent workers from working within their capabilities or seeking another employer [171]).

In addition to technical skills, workers need to consider their cognitive (intelligence) and non-cognitive skills (such as personal traits and emotional stability [172]), which affect the willingness to work and thus can have a major indirect impact on labor productivity. (Non-cognitive skills can influence the use of cognitive skills [173].)

While the level of training and exercise, and especially experience, cannot be improved quickly, motivation of the worker can usually be raised very quickly. However, measures for external motivation are usually of temporary duration, i.e., until the individual's needs are met and thus the motivational cycle is completed [174]. To be effective, the way of motivating should be adapted to the psychological characteristics (preferences) of employees and their needs, because the key motivators of one compared to another worker may differ [175]. In addition, motivation is significantly influenced by work-related perceptions and the work environment [176]. 
Previous research around the world shows the magnitude and frequency of the impact of skills and training of workers, and the importance of training on labor productivity has been confirmed by this research in Croatia. The globally emphasized problem of lack of training (Table 5) and satisfactorily skilled workers grows with the aging of the existing labor (which is very pronounced in Croatia [177], but also in other countries [80]).

All of the above-mentioned points to the importance of investing in the training of workers, both through education and compulsory work. The need for in-service training is emphasized by the deficit of trained construction workers and the frequent arrival in the construction industry of unskilled workers or workers from other professions who need to be retrained. Due to the introduction of new work technologies, lifelong education of workers is needed.

There seems to be a consensus on the lack of skills among construction workers [178], but there is no universal answer as to how best to improve their skills [170]. By achieving increased productivity and reductions in turnover, absenteeism, and rework due to mistakes, investments in employee training return to the employer multiple times $[117,178,179]$.

The significantly weaker impact of school education of workers than professional experience on productivity determined by this research indicates the weaknesses of the school system of education of craft workers in Croatia. The slightest negative impact of school education deficiencies on productivity suggests that workers' skills can be successfully improved with experience and through on-the-job training.

Short training programs or daily courses and seminars in educational institutions with the support of the local construction industry, professional societies, and state authorities are recommended [180].

Fayek et al. [181], Hewage and Ruwanpura [182], Enshassi et al. [183], and Ntuli and Allopi [178] highlight internal mentoring and skills acquisition with internal supervision as the best way to train workers. In addition to basic knowledge, through work in practice, workers also acquire job competencies such as workplace culture, work norms, and values in the organization in which they work. Unskilled workers working on a construction site with good craftsmen can acquire the technical skills of skilled workers in 5 to 10 years [117] and the ability to work independently. As a rule, the acquisition of more skills increases workers' incomes, so they are more satisfied with their work [80] and more motivated to work.

Some of the desirable traits are acquired over time or are lost, and some are immanent to the individual (e.g., dexterity). As a rule, as age increases, so does experience, and physical strength decreases. Although the health of workers has not been included in the survey in Croatia, attention should be paid to the health of workers because it is associated with strength, fatigue, and absenteeism. This is primarily possible through working conditions (appropriate equipment, duration of work) and rests (timely, duration in accordance with the type of work and in good conditions) during the work shift.

\section{Conclusions}

Labor is one of the most important resources of construction contractors. Increasing its productivity means achieving better utilization of labor, which is increasingly scarce and relatively expensive.

Numerous research papers show the impact of different attributes of workers on the productivity of contractors and on the performance of construction projects, but the approach to examining the impact of these characteristics is very diverse (partly justified by regional specifics) and often lacking in previous analysis of interrelationships. Studies dealing with labor productivity do not look into enough detail with respect to differences in worker abilities.

The research conducted in this paper in Slavonia and Baranja defined the direct and indirect influence of important workers' characteristics on productivity. The survey found that "experience in construction" and "dexterity" have a very strong positive impact on productivity, and "strength", "morale" and "school education" have a strong impact. In the absence of these characteristics, all except 
the "school education" have a strong negative impact. This means that none of these characteristics should be ignored and neglected.

This research provides information that can be used in the implementation of measures to properly address issues related to poor productivity on construction projects, as well as the sustainability of the set goals for their realization. Furthermore, the obtained results can be useful for future research on the issue of human resources in construction, in a wider area than the region in which the survey was conducted.

There are several directions for future research. One possible direction would be to monitor the achieved productivity of workers with different characteristics in order to quantify the impact of characteristics on productivity, and to see whether and how much productivity increases with the improvement of worker characteristics. In doing so, one would need to be cautious with regard to the number of other possible factors impacting productivity. Another direction of further research would be to examine the interdependence of individual characteristics of workers, compared to this study where characteristics that were not related were deliberately chosen. In this study, the importance of the researched characteristics of workers was confirmed through their rankings in previous research. However, it is also possible to survey the frequency of deficiencies of these characteristics in the labor force in Croatia.

The workers' characteristics that significantly affect productivity should be kept in mind when managing human resources in the company and on the construction site. Formal education, age, and years of experience are easy to determine, but both cognitive and non-cognitive skills of workers need to be considered, which can also be of influence. The importance of attracting and retaining workers in the company with desirable characteristics and programs for training workers in addition to work and the culture of knowledge transfer in the company were emphasized.

The whole country benefits from increased productivity in construction, so it is justified for the government to encourage the attraction of young labor in construction occupations and to raise the effectiveness of their education.

Author Contributions: Conceptualization, D.V.; methodology, D.V. and S.M.; validation, D.V. and M.H.-N.; formal analysis, D.V.; investigation, D.V.; writing-original draft preparation, D.V. and M.H.-N.; writing-review and editing, D.V. and M.H.-N. All authors have read and agreed to the published version of the manuscript.

Funding: This research received no external funding.

Conflicts of Interest: The authors declare no conflict of interest.

\section{References}

1. Yi, W.; Chan, A.P.C. Critical review of labor productivity research in construction journals. J. Manag. Eng. 2013, 30, 214-225. [CrossRef]

2. Green, B. Productivity in Construction: Creating a Framework for the Industry to Thrive; Chartered Institute of Building: Bracknell, UK, 2016.

3. Ghate, P.R.; Minde, P.R. Importance of measurement of labour in construction. Int. J. Res. Eng. Technol. 2016, 7, 413-417.

4. Liu, M.; Ballard, G.; Ibbs, W. Work flow variation and labor productivity: Case study. J. Manag. Eng. 2017, 27, 236-242. [CrossRef]

5. De Araújo, L.O.C.; Filho, M.C.; Telles, C.H. A New Model of Productivity Management as an Aid to Deadline Management. Available online: https:/www.irbnet.de/daten/iconda/CIB_DC27259.pdf (accessed on 15 June 2020).

6. Nerwal, N. Construction Crew Design: A Lean Approach. Master's Thesis, Michigan State University, East Lansing, MI, USA, 2011.

7. Hatim, R. Construction Management: A Professional Approach of Factors Affecting the Labor Productivity. Int. J. Eng. Tech. Res. 2015, 3, 283-287.

8. Thomas, A.V.; Sudhakumar, J. Factors Influencing Construction Labour Productivity: An Indian Case Study. J. Constr. Dev. Ctries. 2014, 19, 53-68. 
9. Finke, M.R. Claims for Construction Productivity Losses. Public Contract Law J. 1997, 26, 311-338.

10. Park, H.S.; Thomas, S.R.; Tucker, R.L. Benchmarking of construction productivity. J. Constr. Eng. Manag. 2005, 131, 772-778. [CrossRef]

11. Construction Industry Institute. Work Force View of Construction Labor Productivity-RR215-11; Construction Industry Institute (CII): Austin, TX, USA, 2006.

12. Prabhu, G.; Ambika, D. Study on Behaviour of Workers in Construction Industry to Improve Production Efficiency. Int. J. Civ. Struct. Environ. Infrastruct. Eng. Res. Dev. 2013, 3, 59-66.

13. Nasir, H.; Haas, T.C.; Rankin, H.J.; Fayek, A.R.; Forgues, D.; Ruwanpura, J. Development and implementation of a benchmarking and metrics program for construction performance and productivity improvement. Can. J. Civ. Eng. 2012, 39, 957-967. [CrossRef]

14. Soekiman, A.; Pribadi, K.S.; Soemardi, B.W.; Wirahadikusumah, R.D. Factors Relating to Labor Productivity Affecting the Project Schedule Performance in Indonesia. Procedia Eng. 2011, 14, 865-887. [CrossRef]

15. Zidane, Y.; Andersen, B. Causes of Delay and Their Cures in Major Norwegian Projects. J. Mod. Proj. Manag. 2018, 5, 80-90.

16. Asmi, A.; Pratama, J.C.; Safrilah, S. Identifikasi Faktor-Faktor Keterlambatan Dalam Proyek Konstruksi di Jakarta, Seminar Nasional Sains dan Teknologi 2016; Fakultas Teknik Universitas Muhammadiyah Jakarta: Central Jakarta, Indonesia, 2016; pp. 1-12.

17. Hesham, S.A.; Maha, D.A.; Majed, S.A. Causes of delay to public infrastructure projects according to engineers representing different contract parties. Built Environ. Proj. Asset Manag. 2019, 10, 153-179.

18. Abebe, D.G. Causes and Effects of Delay on African Construction Projects: A State of the Art Review. Civ. Environ. Res. 2020, 12, 41-53.

19. Memon, A.H.; Rahman, I.A.; Azis, A.A.A. Preliminary Study on Causative Factors Leading to Construction Cost Overrun. Int. J. Sustain. Constr. Eng. Technol. 2011, 2, 57-71.

20. Memon, A.H.; Rahman, I.A.; Azis, A.A.A. Time and Cost Perfomance in Costruction Projects in Southern and Central Regions of Penisular Malaysia. Int. J. Adv. Appl. Sci. 2012, 1, 45-52.

21. Shebob, A.; Dawood, N.; Shah, R.K.; Xu, Q. Comparative study of delay factors in Libyan and the UK construction industry. Eng. Constr. Archit. Manag. 2012, 19, 688-712. [CrossRef]

22. Wong, K.; Vimonsatit, V. A study of the factors affecting construction time in Western Australia. Sci. Res. Essays 2012, 7, 3390-3398.

23. Gidado, K.; Niazai, G.A. Causes of Project Delay in the Construction Industry in Afghanistan. In Proceedings of the 3rd International Conference Engineering, Project and Production Management, Brighton, UK, 10-11 September 2012; pp. 63-74.

24. Kamanga, M.; Steyn, W. Causes of delay in road construction projects in Malawi. J. S. Afr. Inst. Civ. Eng. 2013, 55, 79-85.

25. Aziz, R.F. Ranking of delay factors in construction projects after Egyptian revolution. Alex. Eng. J. 2013, 52, 387-406. [CrossRef]

26. Gündüz, M.; Nielsen, Y.; Özdemir, M. Quantification of Delay Factors Using the Relative Importance Index Method for Construction Projects in Turkey. J. Manag. Eng. 2013, 29, 133-139. [CrossRef]

27. Ballhysa, V.; Blloku, M. Critical Factors Affecting Construction Cost in Albania. Int. J. Eng. Res. Technol. 2014, 3, 3014-3022.

28. Sweis, J.G. Factors Affecting Time Overruns in Public Construction Projects: The Case of Jordan. Int. J. Bus. Manag. 2013, 8, 120-129. [CrossRef]

29. Sweis, J.R.; Bisharat, M.S.; Bisharat, L.; Sweis, G. Factors Affecting Contractor Performance on Public Construction Projects. Life Sci. J. 2014, 11, 28-39.

30. Jarkas, M.A.; Marenjak, S. Significant contributors to construction cost overruns: Findings of Kuwait. Int. J. Built Environ. Asset Manag. 2014, 1, 193-220. [CrossRef]

31. Marzouk, M.M.; El-Rasas, I.T. Analyzing delay causes in Egyptian construction Projects. J. Adv. Res. 2014, 5, 49-55. [CrossRef]

32. Muhwezi, L.; Acai, J.; Otim, G. An Assessment of the Factors Causing Delays on Building Construction Projects in Uganda. Int. J. Constr. Eng. Manag. 2014, 3, 13-23.

33. Nguyen, Q.T.; Le, T.H.A.; Nguyen, B.N. Time delays causes in construction projects in Hanoi, Vietnam: Contractors' perspectives. In Proceedings of the International Symposium on New Technologies for Urban Safety of Mega Cities in Asia, Yangon, Myanmar, 3-5 November 2014; pp. 1-9. 
34. Shreenaath, A.; Arunmozhi, S.; Sivagamasundari, R. Analysis of factors influencing construction cost overruns in large construction projects of Tamilnadu. Int. J. Eng. Tech. Res. 2014, 2, $42-47$.

35. Sivakumar, S.; Shreenaath, A.; Sivagamasundari, R. A Statistical Study on Critical Factors Influencing Time Overruns in Tamil Nadu Construction Projects. Int. J. Eng. Tech. Res. 2015, 3, 88-91.

36. Kesavan, M.; Gobidan, N.; Dissanayake, P. Analysis of Factors Contributing Civil Engineering Construction Project Delays in Sri Lankan Building Construction Industries. J. Ind. Eng. Res. 2015, 7, 5-11.

37. Bekr, A.G. Identifying Factors Leading to Cost Overrun in Construction Projects in Jordan. J. Constr. Eng. Technol. Manag. 2015, 5, 25-33.

38. Bekr, A.G. Causes of Delay in Public Construction Projects in Iraq. Jordan J. Civ. Eng. 2015, 9, 149-162.

39. Joas, K. Managing Building and Infrastructure Construction Projects: Challenges Encountered in Managing Projects by the DBES. Master's Thesis, Faculty of Applied Sciences Department of Computing, Engineering and Technology, University of Sunderland, Sunderland, UK, 2015.

40. Srdić, A.; Šelih, J. Delays in Construction Projects: Causes and Mitigation. Organ. Technol. Manag. Constr. 2015, 7, 1383-1389. [CrossRef]

41. Gluszak, M.; Lesniak, A. Construction delays in clients opinion-Multivariate statistical analysis. Procedia Eng. 2015, 123, 182-189. [CrossRef]

42. Al-Emad, N.; Nagapan, S. Identification of Delay Factors from Mecca's Construction Experts Perspective. Int. J. Sustain. Constr. Eng. Technol. 2015, 6, 16-25.

43. Gündüz, M.; AbuHassan, H.A.M. Causes of Construction Delays in Qatar Construction Projects. Int. J. Civ. Environ. Eng.-Int. Sch. Sci. Res. Innov. 2016, 10, 531-536.

44. Almutairi, S.N. Causes of delays on Construction Projects in Kuwait according to opinion of engineers working in Kuwait. Int. J. Eng. Res. Appl. 2016, 6, 84-96.

45. Parmar, M.; Bhavsar, J.; Pitroda, J. Identification of Factors Influencing the Cost of Residential Construction Project Work in South Gujarat Region using S.I. Method. Int. J. Adv. Res. Innov. Ideas Educ. 2016, 2, 811-816.

46. Khattri, T.; Agarwal, S.; Gupta, V.; Pandey, M. Critical Causes of Delay in Construction Project in Jhansi Region. Int. Res. J. Eng. Technol. 2016, 3, 567-570.

47. Naveenkumar, G.V.; Prabhu, V. Factors Influencing Time and Cost Overruns in Construction Projects. Int. J. Innov. Res. Sci. Eng. Technol. 2016, 5, 6468-6473.

48. Arya, A.; Kansal, R. Analysing Delays of Construction Projects in India: Causes and Effects. Int. J. Sci. Technol. Eng. 2016, 3, 66-74.

49. Afridi, A.K. Significant Factors of Delay in Construction Projects in Afghanistan. Master's Thesis, Yamaguchi University, Yamaguchi, Japan, 2016.

50. Koshe, W.; Jha, K.N. Investigating Causes of Construction Delay in Ethiopian Construction Industries. J. Civ. Constr. Environ. Eng. 2016, 1, 18-29.

51. Dick-Sagoe, C.; Arthur, C. Construction Professionals' Perspectives on Government's Construction Projects Delays in the Western Region of Ghana. Int. J. Res. Eng. Soc. Sci. 2016, 6, 32-43.

52. Kehinde, A.T.; Lawal, A.F.; Omonori1, A.A.; Olowokere, E.N. Causes and Effests of Delays in Construction Projects in Akure, Ondo State, Nigeria. Futa J. Manag. Technol. 2016, 1, $29-38$.

53. Ogunde, A.O.; Dafe, O.E.; Akinola, G.A.; Ogundipe, K.E.; Oloke, O.C.; Ademola, S.A.; Akuete, E.; Olaniran, H.F. Factors Militating Against Prompt Delivery of Construction Projects in Lagos Megacity, Nigeria: Contractors' Perspective. Mediterr. J. Soc. Sci. 2017, 8, 233-242. [CrossRef]

54. Gebrehiwet, T.; Luo, H. Analysis of Delay Impact on Construction Project Based on RII and Correlation Coefficient: Empirical Study. Procedia Eng. 2017, 196, 366-374. [CrossRef]

55. Oshungade, O.; Kruger, D. A comparative study of causes and effects of project delays and disruptions in construction projects in the South African construction industry. Kicem J. Constr. Eng. Proj. Manag. 2017, 7, 13-15. [CrossRef]

56. Akhund, M.A.; Khoso, A.R.; Memon, U.; Khahro, S.H. Time Overrun in Construction Projects of Developing Countries. Imp. J. Interdiscip. Res. 2017, 3, 124-129.

57. Niazi, G.A.; Painting, N. Significant Factors Causing Cost Overruns in the Construction Industry in Afghanistan. Procedia Eng. 2017, 182, 510-517. [CrossRef]

58. Almaktari, A.M.; Hong, R.; Nzige, J. The Factors influencing Cost Overrun on Construction Projects in Yemen. Int. J. Sci. Eng. Res. 2017, 8, 582-589. 
59. Shahsavand, P.; Marefat, A.; Parchamijalal, M. Causes of delays in construction industry and comparative delay analysis techniques with SCL protocol. Eng. Constr. Archit. Manag. 2018, 25, 497-533. [CrossRef]

60. Aydin, D.; Mihlayanlar, E. Causes and Effects of Construction Project Delays: A Local Case Study in Edirne City Centre. In Proceedings of the 5th International Project and Construction Management Conference, Nicosia, Cyprus, 16-18 November 2018; pp. 478-485.

61. Zaki, A.; Elalim, A.M.A.; El Samadony, A. Factors Affecting Schedule Delay and Cost Overrun in Egyptian Construction Projects. In Proceedings of the 2nd International Conference Sustainable Construction and Project Management-Sustainable Infrastructure and Transportation for Future cities, Aswan, Egypt, 16-18 December 2018.

62. Ramabhadran, M. An Investigation into Cost Overrun in Construction Projects in United Arab Emirates. Int. J. Constr. Eng. Manag. 2018, 7, 1-21.

63. Bajjou, M.S.; Chafi, A. Empirical study of schedule delay in Moroccan construction projects. Int. J. Constr. Manag. 2018, 24, 783-800. [CrossRef]

64. Soewin, E.; Chinda, T. Factors affecting construction performance: Exploratory factor analysis. IOP Conf. Ser. Earth Environ. Sci. 2018, 140, 012102. [CrossRef]

65. Galih, E.P.; Mangitung, M.D.; Kamaluddin, T.M. Factors affecting the delay of the road maintenance project in the application of the long segment method in central Sulawesi. Int. J. Innov. Res. Adv. Eng. 2019, 6, 652-660.

66. Murali, S.; Kumar, S. Factors Affecting Overruns Construction Time and Cost: A Case Study. Int. J. Recent Technol. Eng. 2019, 7, 284-288.

67. Kavuma, A.; Ock, J.; Jang, H. Factors influencing Time and Cost Overruns on Freeform Construction Projects. KSCE J. Civ. Eng. 2019, 23, 1442-1450. [CrossRef]

68. Adedokun, O.A.; Akinmusire, A.O.; Abiola-Ogedengbe, D. Budget Overruns Experienced on Tertiary Institutional Building Projects-Recourse to the Contractors' Related Factors. J. Build. Perform. 2019, 10, $79-84$.

69. Oluyemi-Ayibiowu, B.D.; Aiyewalehinmi, O.E.; Omolayo, O.J. Most Critical Factors Responsible for Cost Overruns in Nigeria Building Construction Industry. J. Multidiscip. Eng. Sci. Stud. 2019, 5, 2500-2508.

70. Arantes, A.; Ferreira, D.F.L.M. Underlying causes and mitigation measures of delays in construction projects-An empirical study. J. Financ. Manag. Prop. Constr. 2020, 25, 165-181. [CrossRef]

71. Dolage, D.A.R.; Chan, P. Productivity in Construction-A Critical Review of Research. Eng. J. Inst. Eng. 2013, 46, 31-42. [CrossRef]

72. El-sokhn, N.H.; Othman, A.A.E. Project Failure Factors and their Impacts on the Construction Industry: A Literature Review. In Proceedings of the 10th International Conference on Civil and Architecture Engineering ICCAE-10 Conference, Cairo, Egypt, 27-29 May 2014; pp. 1-20.

73. Naoum, S.G. Factors influencing labor productivity on construction sites: A state-of-the-art literature review and a survey. Int. J. Product. Perform. Manag. 2016, 65, 401-442. [CrossRef]

74. Dixit, S.; Pandey, A.K.; Mandal, N.S.; Bansal, S. A Study of Enabling Factors Affecting Construction Productivity: Indian Scenerio. Int. J. Civ. Eng. Technol. 2017, 8, 741-758.

75. Nurhendi, R.N.; Khoiry, M.A.; Hamzah, N. Review on Factors Influencing Labour Productivity in Construction Project. Int. J. Recent Technol. Eng. 2019, 7, 837-844.

76. Tammy, N.J.; Medani, M.M.; Ramli, R.; Yunus, J.N.; Mohd Noor, R.N.H.R. Evaluation of Human Factors Influencing Labor Productivity in Construction Project. In Proceedings of the AICCE'19 Transforming the Nation for a Sustainable Tomorrow, Lecture Notes in Civil Engineering 53; Nazri, F.M., Ed.; Springer: Cham, Switzerland, 2019; pp. 1549-1561.

77. Borcherding, J.D. Improving productivity in industrial construction. J. Constr. Div. 1976, 102, $623-638$.

78. Lim, E.C.; Alum, J. Construction productivity: Issues encountered by contractors in Singapore. Int. J. Proj. Manag. 1995, 13, 51-58. [CrossRef]

79. Mojahed, S.; Aghazadeh, F. Major factors influencing productivity of water and wastewater treatment plant construction: Evidence from the deep south USA. Int. J. Proj. Manag. 2008, 26, 195-202. [CrossRef]

80. Huang, A.L.; Chapman, R.E.; Butry, D.T. Metrics and Tools for Measuring Construction Productivity: Technical and Empirical Considerations, Special Publication 1101; U.S. Department of Commerce National Institute of Standards and Technology: Washington, DC, USA, 2009.

81. Inuwa, I.I. Project Planning in Construction Procurement: The Case of Nigerian Indigenous Contractors. Ph.D. Thesis, Jomo Kenyatta University, Juja, Kenya, 2014. 
82. Horner, R.M.W.; Witehead, R.C. Labour productivity on construction sites. In Proceedings of the 2rd Yugoslavian Symposium on Construction Management, Opatija, Croatia, 16-18 April 1986; pp. 587-599.

83. Lim, E.C. The Analysis of Productivity in Building Construction. Ph.D. Thesis, Loughborough University, Loughborough, UK, 1996.

84. Jain, A.; Lone, N.A.; Sharma, A. Improve the Factors Affecting Labour Productivity in Indian Construction Industry. J. Emerg. Technol. Innov. Res. 2020, 7, 494-501.

85. Oštarijaš, Z. Analiza produktivnosti rada na nekim gradilištima u zemlji i SR Njemačkoj. In Proceedings of the 2rd Yugoslavian Symposium on Construction Management, Opatija, Croatia, 16-18 April 1986; pp. 721-728.

86. Vavra, I.; Synek, J. Factors affecting productivity in Czech construction industry 1993/4. In Proceedings of the International Conference Investment Strategies and Management of Construction, Brijuni, Croatia, 20-24 September 1994; pp. 411-416.

87. Hamza, M.; Shahid, S.; Hainin, M.R.B.; Nashwan, M.S. Construction labour productivity: Review of factors identified. Int. J. Constr. Manag. 2019, 1-13. [CrossRef]

88. Gundecha, M.M. Study of Factors Affecting Labor Productivity at a Building Construction Project in the USA: Web Survey. Master's Thesis, North Dakota State University, Fargo, ND, USA, 2012.

89. Ghoddousi, P.; Hosseini, M.R. A survey of the factors affecting the productivity. Technol. Econ. Dev. Econ. 2012, 18, 99-116. [CrossRef]

90. Karim, N.A.; Hassan, S.H.; Yunus, J.N.; Hashim, M.Z. Factors Influence Labour Productivity and the Impacts on Construction Industry. In Proceedings of the AWAM International Conference on Civil Engineering and Geohazard Information Zonation, Batu Ferringhi, Penang, Malaysia, 28-30 August 2012; pp. 724-732.

91. Jimoh, R.A.; Ijigah, A.E.; Elegbede, I. Factors affecting job-site productivity of construction workers in Lagos state. J. Build. Perform. 2013, 4, 67-72.

92. Mistry, S.; Bhatt, R. Critical Factors Affecting Labour Productivity in Construction Projects: Case Study of South Gujarat Region of India. Int. J. Eng. Adv. Technol. 2013, 2, 583-591.

93. Gupta, V.; Kansal, R. Improvement of Construction Labor Productivity in Chambal Region. Int. J. Res. Eng. Technol. 2014, 3, 34-37.

94. Robles, G.; Stifi, A.; Ponz-Tienda, J.S.; Gentes, S. Labor Productivity in the Construction Industry-Factors Influencing the Spanish Construction Labor Productivity. World Acad. Sci. Eng. Technol. Int. J. Civ. Environ. Eng. 2014, 8, 1061-1070.

95. Durdyev, S. Labour Productivity Improvement-Impact Levels of the On-Site Constraints; Scholars' Press: Saarbrücken, Germany, 2014.

96. Hickson, G.B.; Ellis, A.L. Factors affecting Construction Labour Productivity in Trinidad and Tobago. J. Assoc. Prof. Eng. Trinidad Tobago 2014, 42, 4-11.

97. Abdelaal, M.; Farell, P.; Emam, H. Factors Affecting Productivity in GCC Construction Projects. In Proceedings of the 1st International Conference of the CIB Middle East and North Africa Research Network, Abu-Dhabi, UAE, 14-16 December 2014; pp. 557-573.

98. Mahamid, I.; Al-Ghonamy, A.; Aichouni, M. Major Factors Influencing Employee Productivity in the KSA Public Construction Projects. Int. J. Civ. Environ. Eng. 2014, 14, 16-20.

99. Enshassi, A. Constraints to Palestinian Construction Craftsmen Productivity. In Proceedings of the IGLC-22, Oslo, Norway, 25-27 June 2014; pp. 1507-1517.

100. Sherif, M.H.; Remon, F.A.; Enas, S.M.; Madeha, M.A.; Eman, K.A. Critical factors affecting construction labor productivity in Egypt. Am. J. Civ. Eng. 2014, 2, 35-40.

101. Adebowale, O.J. Framework for Effective Management of the Construction Workforce towards Enhancement of Labour Efficiency during the Building Production Process in South Africa. Master's Thesis, Faculty of Engineering, Cape Peninsula University of Technology, Cape Town, South Africa, 2014.

102. Chigara, B.; Moyo, T. Factors Affecting Labor Productivity on Building Projects in Zimbabwe. Int. J. Archit. Eng. Constr. 2014, 3, 57-65.

103. Odesola, I.A.; Idoro, G.I. Influence of Labour-Related Factors on Construction Labour Productivity in the South-South Geo-Political Zone of Nigeria. J. Constr. Dev. Ctries. 2014, 19, 93-109.

104. Lamka, A.H.V. Investigation of factors influencing construction site labour productivity in Nairobi County. Master's Thesis, Jomo Kenyatta University, Juja, Kenya, 2015.

105. Alazzaz, F.A. Assessing Productivity in Off-site Construction Methods for Managing Engineering and Building Projects: An Operational Management Approach. Ph.D. Thesis, Curtin University, Perth, Australia, 2015. 
106. Hazem, R.T.; Adavi, P. Impact of external and human factors on labor productivity of construction projects in Iraq. Int. J. Eng. Sci. Res. Technol. 2015, 4, 432-439.

107. Tahir, M.A.; Hashimhanif; Shahid, Z.A.; Hanif, A. Factors Affecting Labor Productivity in Building. In Proceedings of the 7th IIER International Conference, Singapore, 4 January 2015; pp. 38-43.

108. Anees, M.; Saqib, M.; Memon, D. Identification of Factors Affecting Construction Productivity in Pakistan Industry. Sir Syed Univ. Res. J. Eng. Technol. 2016, 4, 27-31. [CrossRef]

109. Kazaz, A.; Ulubeyli, S.; Acikara, T.; Er, B. Factors affecting labor productivity: Perspectives of craft workers. Procedia Eng. 2016, 164, 28-34. [CrossRef]

110. Gerges, M.; Ahiakwo, O.; Aziz, R.; Kapogiannis, G.; Saidani, M.; Saraireh, D. Investigating and Ranking Labor Productivity Factors in the Egyptian Construction Industry. Int. J. Archit. Eng. Constr. 2016, 5, 44-52. [CrossRef]

111. Mengistu, M.; Quezon, T.E.; Kebede, G. Assessment of Factors Affecting Labor Productivity on Road Construction Projects in Oromia Region, Bale Zone. Int. J. Sci. Eng. Res. 2016, 7, 899-910.

112. Bekr, A.G. Study of Significant Factors Affecting Labor Productivity at Construction Sites in Jordan: Site Survey. J. Eng. Technol. 2016, 4, 92-97.

113. Thiyagu, C.; Dheenadhayalan, D.; Janagan, S. Construction Labor Productivity and its Improvement. Int. Res. J. Eng. Technol. 2016, 3, 1180-1195.

114. Trivedi, R.; Pandey, M. Construction Labour Productivity Factors in Developing City. Case Study: Gwalior. Int. J. Res. Eng. Technol. 2016, 5, 256-259.

115. Shree, R.G.; Murali, K. Analysis of factors affecting labour productivity in construction. Int. J. Recent Sci. Res. 2016, 7, 11744-11747.

116. Tivari, A.; Malik, A.; Singh, C.P. Identification of Critical Factors Affecting Construction Labor Productivity in India Using AHP. Int. J. Eng. Adv. Technol. 2016, 5, 212-220.

117. Sukumar, D.; Kumar, V.R. A study of various factors affecting labour productivity in road construction and suggestions to improve it. Int. J. Sci. Eng. Res. 2016, 7, 98-102.

118. Ahad, M.Z.; Syed, W.A.S.; Sheeraz, M. Practical Labor Productivity Measurement and Its Importance in Construction Projects. Adv. Soc. Sci. Res. J. 2017, 4, 1-9.

119. Durdyev, S.; Mbachu, J. Key constraints to labour productivity in residential building projects: Evidence from Cambodia. Int. J. Constr. Manag. 2017, 18, 385-393. [CrossRef]

120. Hwang, B.-G.; Zhu, L.; Tzu, M.; Jonathan, T. Factors Affecting Productivity in Green Building Construction Projects: The Case of Singapore. J. Manag. Eng. 2017, 33, 04016052. [CrossRef]

121. Construction Productivity in Singapore: Effective Measurement to Facilitate Improvement, A Study by The Singapore Contractors Association Ltd. and Singapore Chinese Chamber of Commerce and Industry. 2017. Available online: https://scal-academy.com.sg/FCKeditor_2.6/editor/filemanager/connectors/userfiles/ file/Paper\%201\%20-\%20Effective\%20Measurement\%20to\%20Facilitate\%20Improvement \%20by \%20Prof\% 20George\%20Ofori(1).pdf (accessed on 16 April 2020).

122. Manoharan, E. Principal Factors Impacting Labor Productivity in Malaysian Construction Industry: A Survey of Constraints on Klang Valley Non-Residential Projects. Int. J. Sci. Eng. Investig. 2017, 6, 9-14.

123. Choudhry, R.M. Achieving safety and productivity in construction projects. J. Civ. Eng. Manag. 2017, 23, 311-318. [CrossRef]

124. Nahod, M.-M.; Knezović, M. Labour productivity in the Croatian conctruction industry: Impact factors from the client's point of view. e-GFOS 2017, 14, 48-57. [CrossRef]

125. Montaser, M.N.; Mahdi, M.I.; Mahdi, A.H.; Rashid, I.A. Factors Affecting Construction Labor Productivity for Construction of Pre-Stressed Concrete Bridges. Int. J. Constr. Eng. Manag. 2018, 7, 193-206.

126. Shriyank, S.; Sandeep, V. Factors affecting labour productivity over construction sector. Int. Res. J. Eng. Technol. 2018, 5, 3152-3155.

127. Annigeri, S.V.; Kelkar, A.A. A Study on Factors Affecting Labour Productivity by Application of Relative Importance Index. Int. Res. J. Eng. Technol. 2018, 5, 781-785.

128. Nguyen, V.T.; Nguyen, L.H.; Nguyen, B.N. Factors Affecting Labour Productivity of Construction Worker on Construction Site: A Case of Hanoi. J. Sci. Technol. Civ. Eng. Nuce 2018, 12, 127-138.

129. Gerami Seresht, N.; Robinson Fayek, A. Factors influencing multifactor productivity of equipment-intensive activities. Int. J. Product. Perform. Manag. 2019, 69, 2021-2045. [CrossRef] 
130. Malara, J.; Plebankiewicz, E.; Juszczyk, M. Formula for Determining the Construction Workers Productivity Including Environmental Factors. Buildings 2019, 9, 240. [CrossRef]

131. Shoar, S.; Banitis, A. Application of Fuzzy Fault Tree Analysis to Identify Factors Influencing Construction Labor Productivity: A High-Rise Building Case Study. J. Civ. Eng. Manag. 2019, 25, 41-52. [CrossRef]

132. Jalal, M.P.; Shoar, S. A hybrid framework to model factors affecting construction labour productivity: Case study of Iran. J. Financ. Manag. Prop. Constr. 2019, 24, 1-28.

133. Alaghbari, W.; Al-Sakkaf, A.A.; Sultan, B. Factors affecting construction labour productivity in Yemen. Int. J. Constr. Manag. 2019, 19, 79-91. [CrossRef]

134. Desai, P.A.; Patil, S.B. A Study of Factors Affecting on Labour Productivity for Precast Fly Over Bridge Construction and Recommendation for Improvement. J. Emerg. Technol. Innov. Res. 2019, 6, 416-419.

135. Agrawal, A.; Halder, S. Identifying factors affecting construction labour productivity in India and measures to improve productivity. Asian J. Civ. Eng. 2020, 21, 569-579. [CrossRef]

136. Jatinkumar, S.B.; Patel, A.S. Factor Affecting Labour Productivity in Construction Industry and It's Improvement. J. Emerg. Technol. Innov. Res. 2020, 7, 249-254.

137. Rakib, F.H.; Howlader, S.; Rahman, M.; Hossain, A. Factors Affecting the Construction Productivity in the Context of Khulna City of Bangladesh. In Proceedings of the 5th International Conference on Civil Engineering for Sustainable Development, Khulna, Bangladesh, 7-9 February 2020; pp. 4932-1-4932-7.

138. Al-Mamlook, R.; Bzizi, M.; Al-Kbisbeh, M.; Ali, T.; Almajiri, E. Factors Affecting Labor Productivity in the Construction Industry. Am. J. Environ. Sci. Eng. 2020, 4, 24-30. [CrossRef]

139. Lefoka, M.; Windapo, A.O. An Examination of Contextual Factors that Cause Variations in Labour Productivity. In The Construction Industry in the Fourth Industrial Revolution-Proceedings of the 11th Construction Industry Development Board 2019; Springer: Cham, Switzerland, 2020; pp. 355-363.

140. Nguyen, Q.T.; Nguyen, V.T.; Dinh, T.H.; Nguyen, L.D.Q. Critical Factors Affecting Labor Productivity within Construction Project Implementation: A Project Manager's Perspective. 2020. Available online: https://www.researchgate.net/publication/344026371_Critical_Factors_Affecting_Labor_Productivity_ within_Construction_Project_Implementation_A_Project_Manager $\backslash T 1 \backslash$ textquoterights_Perspective (accessed on 10 June 2020).

141. Prasad, K.V.; Vasugi, V. Delays in construction projects: A review of causes, need and scope for further research. Malays. Constr. Res. J. 2017, 23, 89-113.

142. Management Methods Manual; Mechanical Contractors Association of America Inc.: Rockville, MD, USA, 2015. Available online: https://www.mcaa.org/pca/wp-content/uploads/sites/3/2016/07/M8PDF.pdf (accessed on 28 May 2020).

143. Durdyev, S.; Ismail, S.; Bakar, N.A. Factors Constraining Labour Productivity: Case Study of Turkmenistan. Int. J. E-Educ. E-Bus. E-Manag. E-Learn. 2012, 3, 18-23.

144. Akogbe, R.-K.; Feng, X.; Zhou, J. Importance and Ranking Evaluation of Delay Factors for Development Construction Projects in Benin. KSCE J. Civ. Eng. 2013, 17, 1213-1222. [CrossRef]

145. Muhammad, N.Z.; Sani, A.; Muhammad, A.; Balubaid, S.; Ituma, E.E.; Suleiman, J.H. Evaluation of factors affecting labour productivity in construction industry: A case study. J. Teknol. (Sci. Eng.) 2015, 77, 87-91. [CrossRef]

146. Seboru, M.A. An Investigation into Factors Causing Delays in Road Construction Projects in Kenya. Am. J. Civ. Eng. 2015, 3, 51-63. [CrossRef]

147. Mulenga, M.; Clinton, A.; Wellington, T. Effects of construction projects schedule overruns: A case of the Gauteng Province, South Africa. Procedia Manuf. 2015, 3, 1690-1695.

148. Nyoni, T.; Bonga, W.G. Towards Factors Affecting Delays in Construction Projects: A Case of Zimbabwe. DRJ J. Econ. Financ. 2017, 2, 12-28.

149. Pal, P.; Pandey, M.; Bhadaoriya, O.P. Factor Affecting Construction Cost and Time in road project. Int. Res. J. Eng. Technol. 2017, 4, 1561-1563.

150. Thorat, S.; Khandare, M.A.; Kanase, A.K. Identifying the causes and effect of delay in residential projects. Int. Res. J. Eng. Technol. 2017, 4, 2993-2996.

151. Alaghbari, W.; Saadan, R.S.N.; Alaswadi, W.; Sultan, B. Delay Factors Impacting Construction Projects in Sana'a-Yemen. Proj. Manag. World J. 2018, 7, 1-28. 
152. Emon, M.B. The main factors working behind the construction delay in Khulna city. In Proceedings of the 4 th International Conference on Advances in Civil Engineering, Chittagong, Bangladesh, 19-21 December 2018; pp. 719-724.

153. Latif, Q.B.a.I.; Al Saadi, A.M.D.; Rahman, I.A. Identification of Delay Factor in Oman Construction Industry. Int. J. Sustain. Constr. Eng. Technol. 2019, 10, 34-45.

154. Murari, S.S.; Joshi, M.A. Factors Affecting Labour Productivity in Precast Construction Industry. In Proceedings of the 4th National Conference on Road and Infrastructure, Bengaluru, India, 4-5 April 2019; pp. 163-169.

155. Govind, S.; Ankit, K.; Samyak, J.; Shanmuga, T.P. Importance of Labour Efficiency in Dry Dock Construction. Int. J. Recent Technol. Eng. 2019, 8, 5737-5741.

156. Fagbenle, O.I.; Ogunde, A.O; Owolabi, J.D. Factors affecting the performance of labour in Nigerian construction sites. Mediterr. J. Soc. Sci. 2011, 2, 251-257.

157. Parizi, C.C.; Naas de Alencar, I.; Garcia, S. Fatores que influenciam na produtividade do trabalhador da construção civil. Rev. Espac. 2017, 38, 26-34.

158. Gündüz, M.; Yahya, A.M.A. Analysis of Project Success Factors in Construction Industry. Technol. Econ. Dev. Econ. 2018, 24, 67-80. [CrossRef]

159. Khair, K.; Mohamed, Z.; Mohammad, R.; Farouk, H.; Ahmed, M.E. A Management Framework to Reduce Delays in Road Construction Projects in Sudan. Arab. J. Sci. Eng. 2018, 43, 1925-1940. [CrossRef]

160. Desai, M.; Bhatt, R. Critical Causes of Delay in Residential Construction Projects: Case Study of Central Gujarat Region of India. Int. J. Eng. Trends Technol. 2013, 4, 762-768.

161. Patel, V.K.; Agrawal, S.; Pandey, M. Study of Factors Affecting Labour Productivity in Construction Industry. J. Emerg. Technol. Innov. Res. 2017, 4, 415-420.

162. Madhan, A.; Gunarani, G.I. Factors Affecting Construction Labour Productivity using Questionnaire Survey. Int. J. Eng. Technol. 2018, 7, 309-313. [CrossRef]

163. Maslow, A.H. Motivation and Personality, 2nd ed.; Harper \& Row: New York, NY, USA, 1970.

164. Vroom, V.H. Work and Motivation; Wiley: New York, NY, USA, 1964.

165. Karthik, D.; Rao, C.B.K. Influence of Human Parameters on Labor Productivity in the Construction Industry. J. Hum. Factors Ergon. Soc. 2019, 61, 1086-1098. [CrossRef]

166. Persons in Pid Employment, by Activities and Counties, Situation as on 31 March 2019, No. 9.2.4, Croatian Bureau of Statistics. Available online: https://www.dzs.hr/Hrv_Eng/publication/2019/09-02-04_01_ 2019.htm (accessed on 30 August 2020).

167. Kombo, D.K.; Tromp, D.L.A. Proposal and Thesis Writing-An Introduction; Paulines Africa: Nairobi, Kenya, 2011.

168. Colton, T. Statistics in Medicine; Little Brown and Company: New York, NY, USA, 1974.

169. Grobler, P.A.; Wärnich, S.; Carrell, M.R.; Elbert, N.F.; Hatfield, R.D. Human Resource Management in South Africa, 2nd ed.; Thomson Learning: London, UK, 2002.

170. Orando, M. The Influence of Human Behaviour Factors on Construction Productivity. Ph.D. Thesis, Department of Quantity Surveying and Construction Management Faculty of Natural and Agricultural Sciences, University of the Free State, Bloemfontein, South Africa, 2013.

171. Herzberg, F. One More Time: How Do You Motivate Employees? Harvard Business Review. Reprint 87507. 1986. Available online: https://kyleshulfermba530.weebly.com/uploads/2/3/4/5/23454770/one_more_time_-_ how_do_you_motivate_employees.pdf (accessed on 30 June 2020).

172. Kautz, T.; Heckman, J.J.; Diris, R.; Ter Weel, B.; Borghans, L. Fostering and Measuring Skills: Improving Cognitive and Non-Cognitive Skills to Promote Lifetime Success; OECD Education Working Papers 110; OECD Publishing: Paris, France, 2014.

173. Brunello, G.; Schlotter, M. Non Cognitive Skills and Personality Traits: Labour Market Relevance and Their Development in Education \& Training Systems; Discussion Paper No. 5743; IZA: Bonn, Germany, 2011.

174. Vidaković, D.; Marenjak, S. Determining Measures to Increase the Productivity of Contractors in Construction Projects. In Proceedings of the 14th International Conference Organization, Technology and Management in Construction \& IPMA 7th Research Conference, Zagreb, Croatia, 4-7 September 2019; pp. 96-111.

175. Naoum, S.G.; Dejahang, F.; Fong, D.; Jaggar, D. A New Framework for Determining Productivity Factors on Construction Sites. In Proceedings of the CIB Joint International Symposium 2009-Construction Facing Worldwide Challenges, Dubrovnik, Croatia, 27-29 September 2009; pp. 109-121. 
176. Parkin, A.B.; Tutesigensi, A.; Büyükalp, A.I. Motivation among construction workers in Turkey. In Proceedings of the 25th Annual ARCOM Conference, Nottingham, UK, 7-9 September 2009; pp. 105-114.

177. Cerić, A.; Ivić, I. Organization. Technol. Manag. Constr. 2020, 11, 2232-2244.

178. Ntuli, B.; Allopi, D. Impact of Inadequate Experience and Skill on the Construction Sector in KwaZulu-Natal, South Africa. Eng. Technol. Appl. Sci. Res. 2014, 4, 570-575. [CrossRef]

179. International Labour Organisation. Building. Civil Engineering and Public Works Committee, General Report: Tenth Session; International Labour Office: Geneva, Switzerland, 1983.

180. Kazaz, A.; Manisali, E.; Ulubeyli, S. Effect of basic motivational factors on construction workforce productivity in Turkey. J. Civ. Eng. Manag. 2008, 14, 95-106. [CrossRef]

181. Fayek, A.R.; Yorke, M.; Cherlet, R. Workforce training initiatives for mega projects success. Can. J. Civ. Eng. 2006, 33, 1561-1570. [CrossRef]

182. Hewage, K.N.; Ruwanpura, J.Y. Carpentry workers issues and efficiencies related to construction in commercial construction in Alberta. Can. J. Civ. Eng. 2006, 33, 1075-1089. [CrossRef]

183. Enshassi, A.A.; Choudhry, R.M.; Alqumboz, M.-A. Safety and Productivity in the Construction Industry. Arab Gulf J. Sci. Res. 2009, 27, 139-155.

Publisher's Note: MDPI stays neutral with regard to jurisdictional claims in published maps and institutional affiliations.

(C) 2020 by the authors. Licensee MDPI, Basel, Switzerland. This article is an open access article distributed under the terms and conditions of the Creative Commons Attribution (CC BY) license (http://creativecommons.org/licenses/by/4.0/). 